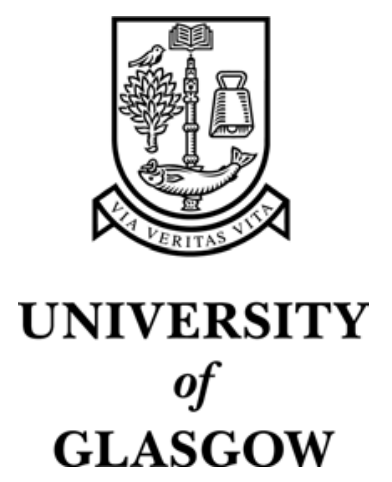

Beattie, V. and Pratt, K. (2003) Issues concerning web-based business reporting: an analysis of the views of interested parties. The British Accounting Review 35(2):155-187.

http://eprints.gla.ac.uk/archive/00000771/ 


\title{
Issues Concerning Web-based Business Reporting: An Analysis of the Views of Interested Parties
}

\author{
Vivien Beattie* and Ken Pratt** \\ (*University of Stirling **formerly University of Stirling) \\ Forthcoming in British Accounting Review, June 2003
}

\author{
Correspondence details \\ Professor Vivien Beattie \\ Department of Accounting, Finance and Law \\ University of Stirling \\ Stirling \\ FK9 4LA \\ Tel. 01786467306 \\ Fax. 01786467308 \\ Email V.A.Beattie@stirling.ac.uk
}

\section{Acknowledgements}

The authors would like to thank the Research Committee of the Institute of Chartered Accountants of Scotland for funding this project. Our thanks go also to those organisations and individuals who assisted us in compiling mailing lists (Stephen Fryer of UKSIP (formerly the Institute of Investment Management and Research), Brian Capon of the British Bankers' Association, Nick Stevens and Margot Owles of the UK Shareholders' Association, Jeremy King and Emma Rees of ProShare, the heads of audit in the largest accountancy firms and senior contacts in financial services companies). Most especially, however, we are indebted to the 538 individuals who gave so freely of their time in completing the questionnaire. The paper has benefited from the comments of participants at the 2001 BAA National Conference, especially Alan Goodacre, and from two anonymous $B A R$ reviewers. 


\title{
Issues Concerning Web-based Business Reporting: An Analysis of the Views of Interested Parties
}

\begin{abstract}
Rapid developments in information and communications technology have led organisations in many countries to consider the impact of the Internet on the delivery and dissemination of business information. This paper reports the findings of a UK study into the views of various user groups, preparers and auditors regarding specific proposals for change and newly emerging practices. Over 500 individuals from six groups responded to a questionnaire study, representing an overall response rate of $33 \%$. Views were elicited regarding (i) the desirability of different kinds of additional information that could be provided electronically, (ii) the usefulness of different navigation and search aids, and (iii) the portability of information under different formats.

It is found that users favour many of the expansions of scope made possible by the web. A range of navigation aids, search aids and file formats are found by all groups to be at least fairly useful, especially global navigation aids. Preferences regarding file formats vary across the groups. Paired group comparisons show that, while expert and non-expert users hold similar views in relation to many issues, users' and preparers' views differ considerably. Auditors' views generally fall in between those of users and preparers. Cyert and Ijiri's (1974) framework is used to rationalise the observed conflicts and congruences of interest, underpinning clear pointers for policy-makers.
\end{abstract}

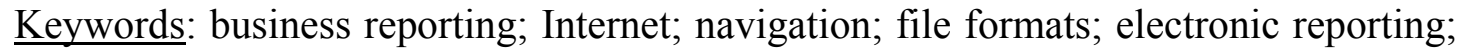
web-reporting 


\section{Issues Concerning Web-based Business Reporting: An Analysis of the Views of Interested Parties}

\section{INTRODUCTION}

Many commentators are predicting that the printed annual report will gradually disappear as corporate reports increasingly move to the worldwide electronic medium of the Internet (e.g. Bury, 1999; Nordberg, 1999; Romain, 2000). Deller, Stubenrath $\&$ Weber (1999) examine the use of the Internet for financial information by the top 100 companies in the US, UK and Germany. They find that over $90 \%$ of US companies provide extensive financial information, with UK and German companies lagging behind. On the demand side, a global study undertaken in 1996 reported that investors ranked websites fourth from bottom out of 23 possible sources of information (the principal reasons given being lack of useful content and difficulty of navigation); by 1998, this information source had risen to 13 out of 26 (Taylor, 1998).

These trends are consistent with both the substantially larger Internet dissemination in the US and the continued growth in all countries. For example, Newsnight reported that $30 \%$ of UK households have access to the Internet (14 November 2000), while a survey by the Office for National Statistics reported in September 2000 that $45 \%$ of adults in Britain have accessed the Internet at some time.

In the UK, Internet reporting has been given further impetus by the Companies Act 1985 (Electronic Communications) Order 2000, which was enacted in December 2000. This allows companies to meet their statutory reporting obligations to shareholders either by distributing annual financial reports electronically or by posting them on the company website and advising shareholders that this has been done. The Company Law Review has generally sought to accommodate changes in information and communications technology. The Final Report recommends that, for listed companies, both preliminary announcements and full annual reports be published on a website with electronic notification of that fact to shareholders that register for this (DTI, 2001, para. 8.86). ${ }^{1} \quad$ The draft Companies Bill (DTI, 2002) requires Internet publication of the annual report within four months of the year-end. Preliminary announcements should also be made available on the Internet. 
A major telephone survey of 1000 private shareholders (weighted to reflect the demographic characteristics of the national population) was undertaken for ProShare in 1999 (ProShare, 1999). It was found that 41\% had access to the Internet, $7 \%$ expressed a current preference for receiving information via the Internet, 25\% said they would in the future consider using the Internet, and 16\% used the Internet as an information source when buying shares.

Clearly, both companies and users see advantages in the use of the Internet to disseminate financial information. Not least for companies, there can be cost savings. The Investor Relations Society in the UK (1998) estimates that it costs between $£ 20,000$ and $£ 30,000$ per annum to maintain financial information on a website, while by comparison it costs, on average, $£ 5$ to send out a copy of the annual report. Thus, web costs are quickly recouped. In addition, the company can both broaden and segment its disclosure audience (Ashbaugh, Johnstone \& Warfield, 1999, p.248). For users, the potential advantages lie in the ease of access and ease of search (Thompson, 1996). Sophisticated, user-friendly software agents provide the user with effective decision-support facilities. Information can be made available more quickly, potentially on a real-time basis. Moreover, use of the Internet means that there is no longer any significant technological or cost constraint on the amount of information that can be disseminated.

These characteristics of Internet reporting mesh well with broader changes occurring in the business environment, in particular the shift towards consumer-driven business and the increasing importance of 'soft' assets such as intellectual capital. (For a review of the forces driving fundamental change and a review and synthesis of many proposals concerning the nature and content of corporate external reporting, see Beattie, 2000). These changes, combined with users' increasing demands for greater transparency from companies, have led organisations and individuals in many countries to question the continued adequacy of the traditional historical financial reporting model for user needs (Lev, 2000; FASB, 2001). This debate has raised the prospect of potentially fundamental changes in business reporting, involving the disclosure of a much greater volume of information, especially forward-looking, nonfinancial and qualitative information. 
To date, most empirical studies of the Internet in relation to financial reporting have documented the web practices of companies. Out of this, best practice guidelines and even frameworks for the development of standards/guidelines in relation to web-based business reporting are beginning to emerge (see, for example, IASC, 1999, chs. 4 and 5; IFAC, 2002). One study surveys firms to investigate the perceived costs and benefits related to establishing an Internet presence (Ashbaugh et al., 1999). Another interviews seventeen UK experts to predict immediate trends in Internet reporting (Jones, Xiao \& Lymer, 2001; Xiao, Jones \& Lymer, 2002).

To the best of our knowledge, however, no studies have asked the interested parties, and especially users, about their attitudes and preferences in relation to Internet reporting. The present study addresses this void by asking six interested groups (four user groups, in addition to preparers and auditors) to give their views regarding (i) the desirability of different kinds of information that could be provided electronically, (ii) the usefulness of different navigation and search aids, and (iii) the portability of information under different formats.

It has been argued that there is a need for standards to be developed in relation to web-based reporting (IASC, 1999, chs.4-5; FRC, 2001, p.36). It is, however, known that users are under-represented in formal lobbying on accounting issues (Weetman, Davie \& Collins, 1996 and references therein). Further, Jonas \& Young (1998) argue that there is insufficient focus on users in the standard-setting process, making knowledge of this group's views of particular value. Thus, the evidence provided by the present survey provides policy-relevant ex ante research in support of the standard-setting process of the type advocated by Schipper (1994) and Jonas \& Young (1998).

Results are provided on each group's absolute views, the level of consensus within the group and the views of each group relative to the other groups. The economic framework of Cyert \& Ijiri (1974) is used to evaluate and rationalise the similarities and differences among and between groups. This, in turn, leads to recommendations for policy-makers. 
The remainder of this paper is structured as follows. Section two provides a review of previous literature relating to Internet reporting and presents the formal research questions. There are three relevant strands to the literature: studies produced in recent years, mainly by professional organisations, that address web-based reporting, empirical surveys of corporate practices, and complementary perspectives on electronic business reporting from the fields of media analysis and technologyadoption. The third section outlines the analytical framework adopted and the survey methods used. Results and analysis are presented and discussed in section four. A final, fifth section summarises and concludes.

\section{PRIOR LITERATURE AND RESEARCH QUESTIONS}

\section{Impact of technology on business reporting}

In recent years, a number of influential articles and reports have considered the impact of developments in information and communications technology on business reporting. Elliott $(1992 ; 1994)$ and Wallman $(1995 ; 1997)^{2}$ were among the first to identify the implications of new technologies for corporate reporting. Elliott (1992) argued that information technology is profoundly changing the way that business is done and that this requires changes in external accounting. He called for greater disclosure of non-financial information, more frequent reporting and less aggregated reporting (pp.74-75). In a subsequent paper, Elliott (1994, p.111) argued that companies could define 'views' into their databases for different user groups.

Similarly, Wallman (1995) argued that there should be additional reporting of soft assets and of business risks, more frequent reporting, and disaggregated reporting via online access to sections of the company's management information system. He proposed a disaggregated, user-controlled 'access' model (1997), pointing out that, due to the low cost of information dissemination and the existence of intelligent agents, there was no longer any rationale for preparers to aggregate information. Users could then use the disaggregated information as inputs to their own customised analytical models.

Issues relating to the structure and nature of a web-based report were addressed in the FauxCom project of the Financial Accounting Standards Board (FASB) (1998). FASB 
launched FauxCom on its website as a sample business information reporting package that responds to and illustrates the information needs of investors and creditors as understood by the American Institute of Certified Public Accountants (AICPA) Special Committee on Financial Reporting (The Jenkins Report, AICPA, 1994). This fully-integrated web-based package was specifically designed to exploit the search, selection and analysis capabilities of modern technology. The package allows drilling down to the desired level of detail and provides navigation buttons which allow the user to jump between the financial statements, the related notes, five-year summaries, and the Management Discussion and Analysis (MD\&A). Graphs are available at the press of a button and information can be downloaded directly to Excel files. In a similar vein, the ICAEW (1998) launched an interactive, prototype annual report, structured as a core report with supplementary reports, at a one-day conference on The $21^{\text {st }}$ Century Annual Report.

Based on detailed survey evidence, ICAS (1999) proposed that: (i) large sections of the corporate database be made available to external users electronically; (ii) information within the database be layered, with links to external information sources and a facility for free search; (iii) information be packaged using templates relevant to each stakeholder group to support non-expert users; (iv) records and minutes of company meetings be accessible electronically with a facility for on-line questioning of management; and (v) the database be updated more quickly and frequently (pp.6878).

The Internet is capable of supporting two-way communication, a feature that is exploited in the ICAS (1999) proposals relating to on-line questioning of management. This facilitates interaction between management and interested parties, thereby enhancing corporate governance structures. ICAS (1999, p.74) suggests that the two principal functions of the Annual General Meeting (AGM), the opportunity for questioning of management by shareholders and voting, could be conducted more effectively via the Internet.

The advantages of electronic financial information are likely to be greatly enhanced by the development of XBRL, which stands for eXtensible Business Reporting Language. ${ }^{3}$ It uses XML (the next generation from HTML) to create documents where 
specific pieces of information are 'tagged' in plain language. This allows for easy exchange of information between formats. The AICPA, in conjunction with others such as the International Accounting Standards Board (IASB), has set up a working party to develop a version of XML for corporate reporting. Every element of the financial statements and the Operating and Financial Review (OFR) will be coded using a simple tag. This technology supports tailor-made extraction of data and comparison across companies (XBRL, 2000). Jensen \& Xiao (2001), who argue for customisation around a standard report, note the importance of XBRL technology in implementing this strategy.

\section{Surveys of company practice}

Over recent years, several studies have documented companies' growing use of their websites for business reporting purposes in addition to promotional and sales material. A few studies have attempted, with limited success, to link the extent of webreporting to company-specific variables (e.g. Ashbaugh et al., 1999; Pirchegger \& Wagenhofer, 1999). Many are single-country studies: US - Petravick \& Gillett (1998); Louwers, Pasewark \& Typpo (1996) and FASB (2000); UK - Hussey, Gulliford \& Lymer (1998); Marston \& Leow (1998); Hussey \& Sowinska (1999);

Craven \& Marston (1999); Financial Director (2000); Accountancy Age (2000); Ireland - Brennan \& Hourigan (2000); Spain - Gowthorpe \& Amat (1999); Sweden Hedlin (1999); and Austria - Pirchegger \& Wagenhofer (1999). Others involve a comparison of several countries: Lymer \& Tallberg (1997) consider the UK and Finland; Deller et al. (1999) consider the US, the UK and Germany. Yet others are worldwide: Taylor (1998) and IASC (1999). Since a summary of many of these studies can be found in IASC (1999, pp.44-46) and FASB (2000, pp. 33-35), only the most recent and wide-ranging studies are considered here. These are summarised in Table 1 .

\section{[Table 1 about here]}

Based on the findings of such surveys, several studies go on to make normative statements regarding web-reporting. Both FASB (2000) and Taylor (1998) emphasise the critical importance of site navigation. FASB (2000) notes that it is very easy to get 'lost in hyperspace' after clicking on several hyperlinks, while Taylor (1998) notes that the first level of site navigation begins on the home page. FASB (2000, pp.21- 
23) also notes that 'one of the most significant decisions in designing financial and business reporting web pages is the use of HTML and PDF file formats'.

HTML documents can be viewed directly in the browser while PDF is a special file format, developed by the Adobe Corporation and requiring a special plug-in. Both formats have advantages and disadvantages. In particular, HTML readily supports hyperlinking but the printed document can look quite different to the original. By contrast, PDF allows hyperlinking out but not into specific places within the file, though it creates documents that are identical to the original printed document both when viewed on screen and when printed. (For a comprehensive comparison, see FASB, 2000, p.22). A project undertaken for the Canadian Institute of Chartered Accountants (CICA) by Trites (1999a,b) emphasises the need for easy export of information into user-designed models, and interactive reporting involving dialogue.

Financial Director (2000) conclude that, inter alia, sites should: (i) have a clear link from the homepage to corporate (and financial) information; (ii) offer an e-mail service, (iii) offer as many different formats as possible (including an HTML version so that the document can be skim read on the web and PDF to allow downloading); and (iv) provide hyperlinking of the notes to the accounts to the relevant sections of the accounts themselves.

Both the IASC (1999) and FASB (2000) studies identify three distinct types of company practice regarding the electronic distribution of business information. IASC describe three 'stages' of reporting: stage I where the printed financial statements are simply 'duplicated' in 'electronic paper' (e.g., PDF); stage II where HTML formatting is used, allowing hyperlinking and indexing; and stage III where electronic enhancements are used to present complex information in alternative ways (pp.47-49). FASB identifies three 'philosophies' underpinning practice: (i) it is seen as a substitute for printed material, (ii) it is seen as a 'complement' to printed material, or (iii) it is seen as a way of innovating the business reporting package, in terms of new information contents and new tools (pp. 39-40). These stages and philosophies appear to map on to each other. 
There appears to be a consensus arising out of these surveys of practice that guidelines or standards in the area of web-reporting are desirable. It is argued that by improving the technological and information quality of reporting on the web, the visibility of business reporting webpages and their integration with wider business analysis would be enhanced (IASC, 1999, p.60). In the short term, IASC (1999) proposes a Code of Conduct that addresses issues such as the relationship of webbased financial information to comparable information published in other modes and formats, usability of web-based information, link integrity on the website, timeliness of information availability, archiving of data from the website and security of the content of the website (pp. 67-68). In the longer term, it is envisaged that new technologies such as XBRL will have been adopted. IFAC (2002) builds on the IASC discussion paper, focussing on control considerations, and recommending that directors and management establish and publish an Internet reporting policy that addresses the what, how and when issues.

\section{Complementary perspectives on electronic business reporting}

The fields of media analysis and technology-adoption provide complementary perspectives on electronic business reporting. In media analysis, four distinct patterns of communication relationship, forming a two-by-two matrix, can be distinguished. The dimensions concern whether control of the information store is central or individual and whether control of the time and subject is central or individual. Business reporting is characterised by central control of the information store and, traditionally, by central control of time and subject (the 'allocution' pattern). The Internet permits a shift towards individual control of time and subject (the 'consultation' pattern). If individuals can choose when and what to attend to from the store of information available, the audience becomes decomposed into sets of information consumers (McQuail, 1997, pp.38-9).

This shift facilitates, in turn, a degree of audience fragmentation, with a movement from a unitary model to either a 'pluralism model' (where limited internal diversification offers diversity in unity) or a 'core-periphery model' (where increased choice results in unity in diversity) (McQuail, 1997, pp.137-8). The ICAS (1999) proposal for the provision of a range of pre-packaged templates for each group of users is suggestive of a pluralism model of communication, while their proposal that a 
free search facility be maintained is consistent with the more advanced core-periphery model. $^{5}$

The technology-adoption literature shows that non-mandatory innovative technology adoption follows a diffusion process (see, for example, Mahajahan, Mueller \& Bass, 1990). Moore (1995) identifies five stages in the process: (i) technology enthusiasts, who gain intrinsic enjoyment from experimenting with new processes; (ii) early adopters, who perceive high value in the use of the new technology; (iii) the early majority (pragmatists), who are concerned about the inherent risks in changing methods; (iv) the late majority (conservatives), who fear technology solutions; and (v) the skeptics, who are the counterpart to the enthusiasts. This technology adoption life cycle applies to both the providers of Internet business reporting packages and the users. $^{6}$

\section{Research questions}

A number of common issues emerge from this review of the extant literature. In relation to the scope, structure and frequency of the business reporting package, these are: the amount and level of aggregation; the tailoring of 'views' to specific groups; the inclusion of information re company meetings; a drill down/layering facility; and the frequency of reporting. The principal issues concerning the support technology are: navigation and search aids; and export file formats.

In addition to group affiliation, two variables that may be associated with individual views are explored. First, company size is known to be a major driver of corporate reporting practices. The competitive nature of the international capital markets encourages companies to make enhanced disclosures and adopt users' preferred formats. The views held by preparers are likely to be an intermediate variable in this relationship, being influenced by company size and, in turn, influencing (and being influenced by) existing company practices. Second, it is known that the dissemination of the Internet is expanding and its use is growing. If it is the case that views are found to be associated with Internet familiarity, then it is possible to predict the direction in which views will change in the future. 
The following research questions (RQs) are therefore addressed for each of the broad issues identified above:

RQ1: What are interested parties' views, on average, regarding each Internet reporting issue?

RQ2: What is the level of within-group agreement?

RQ3: Do the views of the primary interested parties (i.e., expert users, private shareholders, preparers and auditors) differ significantly? If so, which groups differ?

RQ4: Do the views of the expert user sub-groups differ significantly? If so, which groups differ?

RQ5: Are the views of preparers related to company size?

RQ6: What is the nature of the associations between responses to specific issues?

RQ7: Are the views of interested parties related to their familiarity with the Internet?

\section{ANALYTICAL FRAMEWORK AND METHODS}

\section{Analytical framework}

It appears likely that standard-setters will issue either mandatory rules or nonmandatory guidelines regarding Internet reporting. It is the role of standard-setters to provide an environment that, where possible, advances the interests of all interested parties, minimises conflicts and resolves any remaining ones in favour of one group or another. Cyert \& Ijiri (1974) provide a useful economic framework within which to visualise and understand the conflicts and congruences of interests between the three main constituencies in corporate reporting. They identify these constituencies as the Profession, Corporations and Users. The information that each group would like disclosed is represented by a circle. ${ }^{7}$ Thus, areas of overlap between circles correspond to congruence, while the absence of overlap signals a lack of agreement (possibly a conflict). This framework is reproduced in Figure 1. It should be noted that this simple framework assumes homogeneity within each group, an assumption that is unlikely to hold in practice.

[Figure 1 about here -

note that the three circles should be fully closed as on the hard copy] 
The standard-setting process typically requires the collection of systematic evidence on the stated preferences on interested parties, analysis of the similarities and differences within and across parties, consideration of the underlying motivations of interested parties and evidence regarding the costs and benefits of various alternatives to these parties. The present study addresses the first two of these inputs to the process.

Cyert \& Ijiri's (1974) concept of across-group consensus is operationalised using formal statistical tests of differences between groups. Conflicts (i.e. the absence of across-group consensus) are expected to arise where a proposal impacts differently on the various interested parties. The degree of homogeneity within each group is formally measured using the standard deviation of the group's responses. If the standard deviation is high, it would appear that uncertainty exists regarding the true identity and/or magnitude of the costs and benefits to a group with a shared interest. Clearly, different outcome combinations are possible, with the implications for policy-makers varying accordingly.

\section{Sample selection and construction of mailing lists}

As part of a wider study into changes in business reporting, a postal questionnaire was sent to 1,645 interested parties representing four primary groups: expert users (EU), private shareholders (PS), finance directors (FD) and audit partners (AP). The expert user group was further split into three distinct sub-groups - investment analysts (IA), fund managers (FM) and corporate lenders (CL). The importance of distinguishing between buy-side analysts and sell-side analysts has been emphasised by Schipper (1991, p.106) and Barker (1998, p.5). Although both are concerned with equity investment, sell-side analysts do not actually trade and hence their decision processes and attitudes are likely to differ from those of buy-side analysts. ${ }^{8}$ The attitudes of corporate lenders, because they are primarily concerned with non-equity investments, are likely to be different again. The strategies used to identify the samples varied considerably, and relied upon the assistance of various organisations and individuals.

A systematic sample of 410 was selected from a list of the London-based Associate members (total number 1640) of The Institute of Investment Management and Research (IIMR) (now UKSIP). Fund managers were identified from a listing of 
leading firms published in CA Magazine (1999). Corporate lenders were identified with the assistance of the British Bankers' Association (BBA). For each group, there was also an element of direct contact with firms. Private shareholders were contacted with the assistance of UK Shareholders' Association (UKSA) and ProShare. A systematic sample of 421 company finance directors was selected from the population of industrial and commercial UK listed companies in the UKQI list on Datastream in June 2000. ${ }^{9}$ The name of the finance director and contact details were taken from Sequencer and the Hemscott website and checked by telephone. Heads of audit in twelve of the top 20 firms agreed to send out between 1 and 10 questionnaires (93 in total). ${ }^{10}$

\section{Research instrument and questionnaire administration procedures}

The research instrument used primarily closed-form questions and contained four main sections. Section A contained the questions relating to Internet-based information. ${ }^{11}$ The questionnaire began with a short paragraph giving the background to the study, referring to the imperatives for financial reporting created by globalisation, information technology and the needs of the knowledge society. It was also made clear that the questionnaire related to reporting by listed companies only.

There were four main questions dealing with the Internet. The first asked about the frequency with which the respondent used the Internet. The second focused on the proposals identified from the extant literature relating to the scope, structure and frequency of business reporting on the Internet. The third and fourth questions dealt with various navigation aids, search aids and file formats, with questions based primarily on the features of the FauxCom project (FASB, 1998) and FASB (2000).

The questionnaire was pilot tested by six individuals (one audit partner; one fund manager, one finance director and three private shareholders) and the content was revised accordingly. ${ }^{12}$ All questionnaires were serially numbered to allow nonrespondents to be followed up, were accompanied by a personally signed, explanatory letter which included an assurance of confidentiality of responses, and by a stamped, return envelope. Reminder letters were sent after 12 days and a second request (together with another complete research package) was sent after a further 14 days. The first mailing to all groups took place in June 2000. 


\section{RESULTS}

Response rates and tests for bias

A total of 538 individuals responded, giving an overall response rate of 33\%, ranging from $20 \%$ for finance directors to $66 \%$ for audit partners (see Table 2). These response rates are good when compared to those obtained by recent surveys of the same or similar populations. ${ }^{13}$

[Table 2 about here]

To test for response bias, the responses of early and late responders were compared (Oppenheim, 1966, p.34). ${ }^{14}$ A series of t-tests was conducted for each of the 29 questionnaire answers for each group. ${ }^{15}$ Very few significant (at the 5\% level) results emerged and with no consistency across questions. Despite the limitations of such tests (Wallace \& Mellor, 1988; and Wallace \& Cooke, 1990), these results give little indication that response bias is a serious threat to the validity of our results.

\section{Use of Internet by respondents}

Respondents were asked to indicate the frequency with which they used the Internet. Their responses are shown in Table 3 . Across all groups, $60 \%$ used the Internet almost daily; however the frequency of use varied significantly between the four primary groups. The most frequent users were expert users, while the least frequent users were private shareholders. The differences between the four primary groups were statistically significant and pairwise comparisons revealed that private shareholders were significantly less frequent Internet users than each of the other main groups. ${ }^{16}$ There was no significant difference between the three expert user groups.

\section{[Table 3 about here]}

\section{Company size}

For the finance director group, the median size of the 83 responding companies, based on sales, was $£ 68.9 \mathrm{~m}$ (mean: $£ 1,532 \mathrm{~m}$; range: $£ 8 \mathrm{~m}-£ 37,017 \mathrm{~m}) .{ }^{17}$ To allow further analysis, finance directors' responses were divided into two size groups based on the median sales value. There was no significant difference between large and small company finance directors' familiarity with the Internet. 


\section{Presentation of results}

The main findings of this study are presented in Tables 4 to 6 , which share a common layout. Each table addresses a different set of issues. The middle three panels (comprising nine columns) present the mean response, the standard deviation, and (in the case of Table 4 only) whether the response is significantly different from the neutral score of $3^{18,19,20}$ These descriptive statistics relate to RQs 1 and 2, respectively. The final three columns of the table investigate whether any statistically significant differences existed among the four primary groups (RQ3), the three expert user groups (RQ4) and the preparers from large versus small companies (RQ5). Both a parametric analysis of variance (ANOVA) test and an analysis of variance based on ranks (Kruskal-Wallis one-way ANOVA) test were conducted (SAS, 1990, ch.30; Siegel \& Castellan, 1988, pp.206-212). ${ }^{21}$

Having established the existence of a number of differences, parametric multiple comparison procedures based on Tukey's studentised range test (SAS, 1990, ch.24) were used to reveal the source of these significant differences (providing further analysis of RQs 3 and 5). The three-party attestation relationship that exists in business reporting comprises a series of bilateral relationships (Elliott, 1994, p.117). By documenting these pairwise group differences, it is possible to establish a group 'profile' by reference to the other groups. This is useful because the incentives of the groups do differ and this can lead their interests to conflict (Cyert \& Ijiri, 1974). Table 8 provides a summary of the existence and direction of those differences that are significant at the $5 \%$ level. The table focuses on the four primary groups, as there were so few significant differences among the expert user sub-groups. The four primary groups give rise to six paired comparisons.

Findings in relation to RQs 6 and 7 are discussed in the text.

Attitudes to proposals re scope, structure and frequency of web-based reporting Questions relating to the scope, structure and frequency of web-based reporting were developed from proposals by, inter alia, Elliott (1992; 1994), Wallman (1995;1997), and ICAS (1999). Respondents were asked to indicate the extent to which they agreed or disagreed with the proposals, on a Likert-scale of 1 (strongly agree) to 5 (strongly disagree). Responses are summarised and analysed in Table 4. 
[Table 4 about here]

The observed pattern of responses to question 1, which concerns the general amount and type of information that is made publicly available, differs markedly from the other questions. There is neither within-group consensus nor across-group consensus. Both main user groups, on average, favour making key management information available, while finance directors are against this. It appears that respondents are either swayed by concerns about commercial confidentiality or focus on the net benefits of increased information disclosure (principally a reduction in the cost of capital due to a reduction in information risk) (Elliott \& Jacobson, 1994). There is clearly a need for regulators to investigate the nature and magnitude of these costs and benefits further.

Questions 2 to 4 address the way in which information is structured, accessed and packaged. There is reasonably high within-group consensus, but no across-group consensus. Regulators must choose which group's views to give precedence to.

Questions 5 to 8 are proposals designed to widen access to information and reduce any unfair advantage. ${ }^{22}$ Views across groups differ significantly, with both user groups tending to agree more strongly (or disagree less strongly) than finance directors. The practices of placing records of general meetings on the website and archiving an audio-visual record of these meetings are widespread among the largest companies. For example, Arthur Andersen (2001) report that 21 of the top 25 FTSE companies adopt at least one of these practices. This finds favour with users. The practice of webcasting (or broadcasting via satellite television) these meetings is noted with favour by FASB (2000, p.ix and p.12). However, there is no support from any group for this. In relation to one-to-one meetings, the two main user groups are split. Expert users are against the proposal to place detailed minutes on the website while PSs are in favour, perhaps because these meetings are the source of potential comparative information advantage.

The future role of AGMs (questions 7 and 8) has been the subject of considerable debate in recent years, with many of the arguments being captured in the DTI 
Consultation Document Company General Meetings and Shareholder Communication (DTI, 1999) and the Company Law Review (DTI 2000, pp.92-104). Following consultation, the overall conclusion was that AGMs should not be abolished, but that developments in technology should be used to preserve their essential functions while avoiding acknowledged defects. Instead, it was suggested that technology be used to hold dispersed meetings, connected by communication links (DTI, 2000, para. 4.31). The Final Report of the Company Law Review and the draft Companies Bill, however, shift position slightly and recommend that public companies be allowed to dispense with AGMs if members so decide; the Final Report also recommends that electronic voting be permitted (DTI, 2001, paras. 7.6 and 7.11; DTI, 2002). The proposal to webcast AGMs is opposed only by finance directors (albeit mildly). ${ }^{23}$ Company management carefully rehearses company meetings, but AGMs can be unpredictable and management may fear the consequences of disseminating unwelcome questions more widely. The proposal to replace company AGMs by a facility for on-line questioning of management and on-line voting was rejected by all main groups, most strongly by private shareholders.

Finally, questions 9 and 10 concern information updating on the website. Question 9 elicited preferences for periodic versus continuous updating and revealed a broad consensus in favour of periodic updating, sending a clear signal to policy-makers. It appears that market makers prefer the structure and discipline of periodic review linked to reporting cycles (ICAS, 1999). Richardson \& Scholz (2000) identify two other possible reasons for the preference for periodic reporting - companies' systems may be technologically unable to support continuous reporting and there may be fear of litigation as a result of inadequate vetting of information.

The final panel of Table 4 shows that the four primary groups generally hold different views (with the exception of question 9), while the three expert user groups hold very similar views (with the exception of question 4). The views of large and small company finance directors differed on selected questions, in particular those concerning general meetings. The detailed nature of these differences, reported below in Table 8, reveal that both user groups tend to favour nearly all of the proposals significantly more that finance directors. 
To address RQ6, the correlations (Spearman) between the responses to these questions were examined. All were positive and all but 11 of the 66 (i.e., [(12 $\times 12)$ $12] \div 2$ ) were significant at the $1 \%$ level. There were three clusters of correlations in excess of 0.30: (i) among questions $1-4$, (ii) among the three parts of question 5, question 6 and question 7, and (iii) between question 4 and questions 5 - 7. This indicates that, in general, those respondents that favoured more information also favoured more structuring of the data (questions 2 and 3) and the ability for users to undertake their own searches (and vice-versa). Respondents also consistently supported (or rejected) wider access to company meetings. Perhaps less obviously, however, those that supported user control over the search process also tended to support wider access to company meetings. Perhaps it is felt to be particularly important that unstructured and often narrative material of this type should be searchable.

Turning to RQ7, the correlations (Spearman) between frequency of Internet use and responses to the ICAS proposals were not generally very high. More frequent Internet users were, however, associated (at the 5\% level) with stronger agreement with questions 1, 2, 5 (all three parts) and 8 . The highest correlation was with question 8 (replacement of AGMs) - a correlation of -0.23 (where 'frequency of Internet use = never' is coded 1 and 'almost daily' is coded 4). This response is perhaps driven by the attitudes of those less familiar with the Internet, who would lose de facto access to the shareholder democratic process under this proposal.

\section{Usefulness of navigation and search aids}

The introduction to this set of questions is shown in the Appendix. Respondents were asked how useful they thought each listed feature would be (on a scale of 1 (very useful) to 5 (not useful at all)). Results are presented in Table 5. The general pattern of results across groups and questions is very consistent, in that all groups consider all features to be useful, with reasonably high levels of within-group consensus.

\section{[Table 5 about here]}

Question 1 addressed the ease with which business reporting information could be located from the home page. Ashbaugh et al. (1999, p.251) in particular regard the 
practice of indexing financial information on the home page as improving the usefulness of disclosures. This is the feature ranked by all main groups as most useful out of the 11 listed. The existence of a hyperlinked table of contents for the business reporting package (question 2) is identified as a useful navigation aid by FASB (2000, p.23). ${ }^{24}$ This is ranked as either the second or third most useful feature by all main groups.

The next two multi-part questions address the value of hyperlinks between different sections of the business reporting package. The importance of hyperlinks is endorsed by Ashbaugh et al. (1999). The FauxCom demonstration site (FASB, 1998) incorporates a number of these 'jump gates'. The link considered most useful is that between the financial statement line item and the corresponding note to the accounts. The financial statement line item appears to be the primary information hub, whereas the OFR is a secondary hub. The link between these two hubs is ranked second.

The FauxCom site also provides a wealth of graphic information - by 'pointing and clicking' on financial items it is possible to get a time series graph of the item. This type of feature ranks quite far down the list for the main groups, whereas the provision of 'next' and 'previous' buttons on each web page ranks more highly. This latter aid, identified in FASB (2000, p.24), allows users to move through the report in a linear fashion in the same way as the paper-based annual report. ${ }^{25}$ Finally, the facility to sign up for e-mail alerts (identified as a notable practice by FASB, 2000, p.13), was ranked moderately highly.

There is a high degree of within-group consensus across all questions in this set, but no across-group consensus. One or other of the user groups rated several of the hyperlinks more highly than finance directors, while both user groups rated the graph facility more highly than finance directors. This lack of consensus is unlikely to arise from a conflict of interest per se; it is simply reflecting different perspectives. In the absence of regulatory intervention, however, it seems likely that there will be a significant underprovision of such features on websites.

An examination of the correlations (Spearman) between the responses to these questions (RQ6) showed, not surprisingly, that all were positive and all of the 55 (i.e., 
$[(11 \times 11)-11] \div 2)$ were significant at the $1 \%$ level. All were in excess of 0.25 and 14 were in excess of 0.50 . While there are 5 (out of 6 ) significant differences between the primary groups, there are no significant differences between the views of the three expert user groups and only one significant difference between the views of large and small company FDs. The detailed nature of these differences is further explored in a separate sub-section below.

Perhaps surprisingly, the correlations (Spearman) between frequency of Internet use and the usefulness of navigation aids (RQ7) were not generally very high. More frequent Internet users tended to believe that four features, in particular, were useful (based on associations at the 5\% level): index on home page; hyperlinked site map or table of contents; hyperlinks between the financial statements and the notes; and email alerts.

\section{Usefulness of different file formats}

Findings on the usefulness of five distinct file formats are reported in Table 6. Each of the formats is seen as being at least 'fairly useful' by all groups. There are, however, distinct differences in the rankings of the groups. Table 7 presents the rankings of these five file formats for each main group, indicating where the significant differences lie. Expert users rank the spreadsheet format clearly top. Private shareholders, by contrast, rank HTML, then word-processed and spreadsheet formats closely together at the top.

[Tables 6 and 7 about here]

The final question in this section asks about the usefulness of the principal feature of $\mathrm{XBRL}$ - its use of type tags that allow automatic inter-company comparisons. These tags provide information about information, i.e. 'meta-information' (Elliott, 2001). Both expert users and audit partners rate this as useful.

The responses to only two questions in this section are significantly correlated (at the $5 \%$ level) with frequency of Internet use (RQ7) - questions 2 and 4. The correlations with questions 3 and 5 are significant at the 10\% level. All correlations are negative. 
Thus, not surprisingly, this shows that more frequent Internet users rate the usefulness of various file formats (other than HTML) as more useful than less frequent users.

Looking across the questions relating to navigation aids, search aids and file formats, it is possible to observe the relative rankings of these features. In general, it would appear that global navigation aids (such as indexing on home page and hyperlinked table of contents) are rated most useful by all groups, with local navigation aids (i.e., detailed hyperlinks) and then alternative file formats following behind.

\section{Paired group comparisons}

The results in Table 8 are policy-relevant because they pin down the source of differences between different groups. For policy-making purposes it is not enough simply to know that different groups hold significantly different views. The findings in Table 8 indicate, for example, cases where different user groups have significantly different views (indicating a systematic lack of user homogeneity), where users and preparers have significantly different views (indicating possible conflicts of interest), and where preparers have significantly different views (indicating a systematic lack of preparer homogeneity). Different patterns emerge from these detailed group comparisons and the appropriate policy-response should take these specific patterns into account. It may be that reporting requirements need to be targetted at different user audiences, or that differential requirements for large and small listed companies are called for. The latter idea has, for example, been put forward in the draft Companies Bill OFR proposals.

[Table 8 about here]

Looking at Table 8 as a whole, rather than item by item, allows the response profiles of each group to be compared and contrasted. There are only six points on which expert users and private shareholders differ. Expert users are more in favour of replacing AGMs, and of spreadsheet and XBRL file formats (the latter containing type tags). They are less in favour of making details of one-to-one meetings public, and HTML and PDF file formats. The findings in relation to file formats are likely to reflect the relatively higher computer literacy of expert users and also differences in the degree of structure of the user groups' methods of analysis. 
There are many more points of difference between users and finance directors. Both user groups are more in agreement than finance directors with most of the ICAS proposals regarding the content and general nature of the web-based business reporting package. Not surprisingly, preparers (at least a significant number) have concerns about extending the scope of the information package (due, perhaps, to fears regarding commercial sensitivity or litigation risk). There are five proposals with which the finance director group are in significant disagreement: making key information available; broadcasting/webcasting general meetings; placing minutes of one-to-one meetings on web; webcasting AGMs; and replacing AGMs with on-line questioning. Yet in each case, a minority (in some cases a substantial one) is in agreement: $36 \%, 16 \%, 8 \%, 25 \%$ and $22 \%$, respectively. Users also rate a number of Internet features as being more useful than finance directors do - in particular, certain hyperlinks and (for expert users only) spreadsheet formats and type tags.

There are rather fewer points of difference between users and audit partners, although the direction of effect is the same, with users perceiving a higher degree of usefulness. The differences between finance directors and audit partners are also less in number than between users and finance directors. To the extent that the proposals/features under consideration have specific implications for the auditor as a provider of assurance services, their responses will reflect this distinct outlook. For example, audit partners are the group that is most strongly in agreement with the proposal to identify clearly the frequency of information updating.

In general, however, the picture is one where audit partners' views fall between the views of users and preparers. The audit partners are members of a professional body that has public interest responsibilities, yet it is the company with which the auditor has the closest relationship. It is to be expected, therefore, that auditors will be more aware than users of the problems in implementing the proposed changes in business reporting. In addition, it is the company management and not the users who effectively appoint and set the remuneration of the auditor. For this reason, auditors may feel obliged (consciously or sub-consciously) to lobby on behalf of the client company (Watts \& Zimmerman, 1986, ch.13). Auditors can also be expected to 
exhibit a degree of self-interest, linked to the risks and returns available from the provision of auditing services.

The final column of Table 8 reports the direction of the significant differences between the large and small company finance directors. ${ }^{26}$ As might be expected, in all cases of difference, it is the large company finance directors who express the more positive view. They are clearly more willing to place key information and information re general meetings in the public domain. There may, therefore, be a case for different regulation for large and small listed companies, an approach suggested in the draft Companies Bill (DTI, 2002).

\section{SUMMARY AND CONCLUSIONS}

Using a postal questionnaire, this study (i) uncovers interested parties' level of agreement with proposals for developing the business reporting package that are dependent on electronic delivery, and (ii) elicits from these parties views regarding the usefulness of a variety of features of web-based reports, many of which represent best practice as identified by FASB (2000). The conflicts and congruences of interest in relation to proposals about the scope, structure and frequency of business reporting were evaluated using Cyert and Ijiri's framework. Inter-group differences about the usefulness of specific web features are unlikely to arise from fundamental conflicts of interest; instead they reflect the different perspectives of each group. In such cases, to bring about the state of affairs desired by users, it may be sufficient to make preparers aware of users' preferences.

The views of the main constituent groups differ significantly with respect to the scope, structure and frequency of web-based reporting packages. While users favour most of the specific proposals listed in Table 4, finance directors are neutral or oppose them, with audit partners tending to fall somewhere in between. It is clearly important for policy-makers to evaluate whether the opposition of finance directors is based on legitimate concerns; if not, then the user focus towards company reporting requires that policy-makers mandate those proposals that carry user support. 
The strongest opposition to any proposal from any group comes from finance directors in relation to the proposal to place the minutes of one-to-one meetings on the web: $76 \%$ oppose this; $16 \%$ are neutral and only $8 \%$ agree. Expert users also generally oppose this, but $30 \%$ agree, despite the fact that such meetings are viewed as a critical information source by this group, as it is a means of gaining competitive advantage. The relative strength of feeling is interesting. Holland (1998a;b) provides a useful insight into finance directors and expert users perceptions of such meetings. They are seen as facilitating a 'dual knowledge advantage', whereby the existence of external monitoring by financial institutions sharpens up the process of internal debate (1998a, p261). Companies expressed the view that, if such meetings became open (as they would if minutes were placed on the web), many of the relationship advantages would be lost (Holland, 1998b, p.51).

All main groups (especially private shareholders) oppose replacing the AGM by online questioning. Finance directors and audit partners oppose webcasting general meetings and finance directors oppose webcasting AGMs and making key information available.

Where interested parties tend to agree amongst themselves, but not across groups, it appears that the costs and benefits to each party are clearly understood, but impact upon the groups differently. The policy-maker must act as arbiter given such conflicts of interest. However, where groups don't agree amongst themselves on the desirability of a given proposal, further investigation is required to establish the nature and magnitude of the costs and benefits to different parties. This investigation must precede policy-making.

Turning now to the usefulness of the range of features of web-based reporting intended to increase the value of the information provided by increasing its usability, it was found that all of the features were considered by all groups to be, on average, at least 'fairly useful', i.e., mean $<3$. Many were considered to be 'useful', i.e., mean < 2. Global navigation aids were considered most useful. The only significant differences between the two main user groups was in relation to file formats, with expert users preferring the formats that enabled subsequent analysis and modelling. In several cases, users rated features as being significantly more useful than finance 
directors (or to a lesser extent audit partners) did. It is finance directors who can exert the most direct influence on the overall architecture of a site and there appears to be no prima facie reason why users' preferences on these issues should not be accommodated. These findings suggest, therefore, that either finance directors need to be informed as to user preferences or, if this does not bring forth the required changes in website design, policy-makers could intervene to set best practice guidelines. The latter approach could greatly speed up the diffusion of technology innovation.

Several possible explanations exist for the low levels of within-group agreement observed for many Internet issues. One explanation emerges from the technology adoption literature. Given that the respondents are likely to represent the five stages in the process of technology adoption, it is perhaps not surprising that the level of agreement within groups is fairly low. Another explanation stems from the heterogeneous nature of many of the main constituent groups. For example, the cost and benefits of increased public disclosure for preparers may depend upon companyspecific factors.

A notable finding of the study is that virtually no significant differences are found between the views of the three expert user groups in relation to web-reporting. Thus, there appears to be no need for future research to consider their needs on such matters separately. The views of large company finance directors were significantly more positive (i.e. more in agreement) than those of small company finance directors in relation to certain proposals, especially those dealing with expanding the public disclosure of information. Familiarity with the Internet also tended to result in more positive views from all constituents for a minority of issues.

This study identifies those issues upon which there is cross-group consensus that a particular state of affairs is desirable. If this state of affairs is not the one currently prevailing, then this indicates issues for immediate action, whether implemented voluntarily by companies, encouraged by non-mandatory guidelines or introduced via mandatory standards. The strength of feeling is an indicator of the importance with which the issue should be addressed. By identifying those issues upon which there is a lack of consensus across groups, the study shows where policy-makers may have to intervene to resolve conflicts or enhance usability. Further research is required to give 
a clear indication of which group's views should be supported by the policy-makers. In particular, there is an urgent need to evaluate the extent to which FDs' concerns regarding expansion of the reporting package are legitimate.

The study has three specific limitations, in addition to those inherent in the questionnaire method of investigation. First, the extent to which members of UKSA and ProShare are representative of the population of private shareholders is unknown. They might, by virtue of their membership of these associations, be more interested in the issues and more willing to offer an opinion, although it is not clear why their views would be systematically different from the population's view. Second, the views of financial company finance directors are not sampled, although once again it is not clear how or why industry membership might influence views. Third, the study is limited to the UK setting and UK participants. Since the benefits of Internet reporting are potentially of greater value to cross-border investors compared to domestic investors, domestic users' views might not be fully representative. Further research is required to investigate these issues. 


\section{ENDNOTES}

${ }^{1}$ The APB (2001) Bulletin offers guidance to auditors in relation to web-based reporting. Auditors should review the process of electronic publication, check that the contents of the electronic version are identical to the hard copy, and check that there is no distortion in overall presentation. If not satisfied, auditors should refuse to give consent to the electronic release of their audit opinion. The wording of the auditors' report should be altered to refer to the financial statements by name rather than by page number.

${ }^{2}$ Wallman is a former SEC Commissioner.

${ }^{3}$ XBRL was previously known as XFRML (eXtensible financial reporting mark-up language).

${ }^{4}$ The introduction to the FauxCom website and IASC (1999, pp.26-30; 41-43; 48; and 74-75) make many of the same points.

5 This perspective is consistent with the shift from 'push' to 'pull' communications in investor relations. The old push paradigm is characterised by the provision of batch-processed, producer-driven information, whereas the new pull paradigm is characterised by the provision of tailored, customerdriven information (Sabey, 1999). These changes in the field of media analysis are also consistent with the changes taking place in business generally, whereby mass production and mass consumption are giving way to 'mass customisation'. Byrne argues that the $21^{\text {st }}$ century corporation 'will tailor its products to each individual by turning customers into partners and giving them the technology to design and demand exactly what they want' (2000, p.47).

${ }^{6}$ Walsh \& White (2000) provide an analysis of the technology adoption life cycle as applied to electronic filing of tax returns in the US.

${ }^{7}$ Note that the present study examines not only what is disclosed, but also the manner of its disclosure.

${ }^{8}$ Members of UKSIP (formerly IIMR) tend to be employed primarily as sell-side analysts. Some, however, work for money management funds or institutional investors (buy-side). As not all respondents gave their position or organisation (some questionnaires were sent to home addresses), it was not possible to maintain a rigorous distinction between these two groups.

${ }^{9}$ The UKQI list was identified as a systematic listing of UK listed companies for which Datastream holds accounting information. It does have the disadvantage that financial companies are excluded. There is, however, no a priori reason to expect that the inclusion of a few responses from financial company finance directors would alter the findings in any material respect.

${ }^{10}$ All the Big Five firms took part. A number of the second tier firms felt unable to take part because they had so few listed company clients. (Due to the nature of the study, it was particularly important that only audit partners responsible for listed clients take part.)

11 Section B (concerning content), section C (concerning assurance) and section D (concerning regulatory reform) are (or will be) reported in separate reports.

${ }^{12}$ It became clear during piloting that the private shareholder group in particular would find some of the issues being dealt with very unfamiliar and difficult. Unfortunately, some of the issues covered by the questionnaire are complex and cannot readily be simplified. In the end, we decided that it was important to obtain this group's views so that they could be compared with those of expert users. We therefore adopted a number of strategies for dealing with some respondents' difficulty with the questions: (i) we specifically asked, in the second question, whether respondents thought that private shareholders should be consulted on issues to do with company external reporting, (ii) we tried to explain clearly all potentially unfamiliar terms and concepts, and (iii) we included an explicit 'don't know' response category.

${ }^{13}$ To give an indication of comparable response rates, we reviewed three journals (Accounting and Business Research, British Accounting Review and Accounting Horizons for the three years 1998-2000 to identify postal questionnaire studies using similar groups and also reviewed postal questionnaire user needs studies published in the last few years. In the UK, Clatworthy (2000) obtains a response rate of $20 \%$ for UK investment analysts (IIMR associate members); Solomon (1999) obtains a response rate of $22 \%$ for UK institutional investors; Bartlett \& Chandler (1997) obtain a response rate of $25 \%$ from UK private shareholders; and Bebbington, Gray, Thomson \& Walters (1994) obtain a response rate of $18 \%$ from the finance directors of the top 1000 UK companies. In Australia, Yap (1997) obtains a response rate of 35\% from a mixed group of Australian expert users; and Deegan \& Rankin (1999) obtain response rates of $25 \%$ from groups of senior executives of the largest companies in Australia and also from a range of users. In the US, Hermanson (2000) obtains an overall response rate of $28 \%$ across nine groups of users, preparers and auditors in the US; Ashbaugh et al. (1999) obtain a response rate of 
27\% from US listed companies; Ayers \& Kaplan (1998) obtain a response rate of 32\% from Big Six audit partners; while Thomas, Davis \& Seaman (1998) and Viator (1999) obtain response rates of 35\% and 30\%, respectively, from CPAs. Milne \& Chan (1999) obtain response rates of $21 \%$ and $25 \%$ from investment analysts and accountants, respectively, in New Zealand. In a comparative study, Anderson \& Epstein (1996) obtain response rates of $10.4 \%, 18.5 \%$ and $25 \%$ from private shareholders in the US, Australia and New Zealand, respectively. Response rates are influenced by a range of factors, such as questionnaire fatigue of the population; interest in the topic; the attractiveness and professionalism displayed in the design and presentation of the questionnaire; and the thoroughness of the administration procedures.

${ }^{14}$ Recourse had to be made to this surrogate method as key characteristics of the various populations and samples were, in general, unavailable.

${ }^{15}$ Anderson \& Epstein (1996) and Deegan \& Rankin (1999) conduct similar series of tests for nonresponse bias.

${ }^{16}$ Based on ANOVA tests and subsequent paired comparison tests described later in the paper.

${ }^{17}$ The median size in terms of total assets was $£ 47.2 \mathrm{~m}$ (mean: $£ 1,398 \mathrm{~m}$; range: $£ 0.6 \mathrm{~m}-£ 29,569$ ). The Pearson correlation between both size measures was 0.927 .

${ }^{18}$ In the results tables, space does not always permit the full text of each question to be included (this is given in the Appendix).

${ }^{19}$ Opinion varies regarding whether it is better to use parametric or non-parametric statistical tests on responses from Likert-type scales. Strictly, a Likert scale is not an interval scale and so the more conservative non-parametric tests should be used; in practice, however, the results of both forms of statistical tests are very similar and so the more familiar and tractable parametric versions are commonly used. Studies involving Likert scales that use parametric tests include Bebbington et al. (1994), Yap (1997) and Hermanson (2000), while Deegan et al. (1999) use non-parametric tests exclusively.

${ }^{20}$ Frequency distributions for the four primary groups, together with qualitative evidence from 16 follow-up interviews, are reported in a separate report prepared for the funding body by the present authors (Beattie \& Pratt, 2001). That report does not undertake any detailed statistical analysis of the responses.

${ }^{21}$ To examine the impact of company size on finance directors' responses, we also undertook a series of simple regressions using $\ln$ (sales) as the explanatory variable. The results were essentially the same as those reported using the t-test (i.e. questions where the explanatory variable was significant), although the level of significance was generally higher.

${ }^{22}$ Attitudes to differential access were investigated in ICAS (1999). There was a widespread belief (74\%) that company meetings (in particular one-to-one meetings) created the perception of unfair advantage, while approximately half thought there was actual unfair advantage. On the basis of these findings, ICAS (1999) proposed that access to company meetings be extended.

${ }^{23}$ A US survey has shown that, in mid 1999, 10\% of the survey population used the Internet to broadcast annual meetings, with a further 25\% actively considering it (reported in FASB, 2000, p.8).

${ }^{24}$ FASB (2000, p.23) reports that $71 \%$ of the US sites surveyed included this feature.

${ }^{25}$ FASB (2000, p.24) reports that $42 \%$ of the US sites surveyed included this feature.

${ }^{26}$ In the case of two groups, the parametric ANOVA reduces to a simple t-test (the non-parametric equivalent is the Wilcoxon test). 


\section{REFERENCES}

Accountancy Age (2000). 'The good, the bad and the ugly', 2 November, pp.14-15.

AICPA (1994). Improving Business Reporting - A Customer Focus: Meeting the Information Needs of Investors and Creditors, Comprehensive Report of the Special Committee on Financial Reporting (The Jenkins Report), New York, NY, American Institute of Certified Public Accountants.

Anderson, R H. \& Epstein, M.J. (1996). The Usefulness of Corporate Annual Reports to Shareholders in Australia, New Zealand, and the United States: An International Comparison, Greenwich, CT, JAI Press.

APB (2001). The Electronic Publication of Auditors' Reports, Bulletin 2001/1, London, Auditing Practices Board.

Arthur Andersen (2001). It's Raining News: A Study of More Frequent Reporting by Larger Companies, June, London.

Ashbaugh, H., Johnstone, K.M. \& Warfield, T.D. (1999). 'Corporate reporting on the Internet', Accounting Horizons, 13(3), September, pp.241-257.

Ayers, S. \& Kaplan, S.E. (1998). 'Potential differences between engagement and risk review partners and their effect on client acceptance decisions', Accounting Horizons, 12(2), June, pp.139-153.

Barker, R.G. (1998). 'The market for information - evidence from finance directors, analysts and fund managers', Accounting and Business Research, 29(1), Winter, pp.3-20.

Bartlett, S.A. \& Chandler, R.A. (1997). 'The corporate report and the private shareholder: Lee and Tweedie twenty years on', British Accounting Review, 29(3), September, pp.245-261.

Beattie, V.A. (2000). 'The future of corporate reporting: a review article', Irish Accounting Review, 7(1), pp.1-36.

Beattie, V. \& Pratt, K. (2001). Business Reporting: Harnessing the Power of the Internet for Users, Edinburgh, Institute of Chartered Accountants of Scotland.

Bebbington, J., Gray, R., Thomson, I. \& Walters, D. (1994). 'Accountants' attitudes and environmentally-sensitive accounting', Accounting and Business Research, 24(94), Spring, pp.109-120.

Brennan, N. \& Hourigan, D. (2000). 'Corporate reporting on the Internet by Irish companies', The Irish Accounting Review, 7(1), pp.37-68.

Bury, L. (1999). 'On line and on time', Accountancy, August, pp.28-29.

Byrne, J.A. (2000). 'Management by web', Business Week, August 28 ${ }^{\text {th }}$, pp.44-52. 
CA Magazine (1999). 'Who’s who in fund management 1999', December, pp.31-70.

Clatworthy, M. (2000). 'Transnational equity analysis - an evaluation', Professional Investor, September, pp.22-24.

Craven, B.M. \& Marston, C.L. (1999). 'Financial reporting on the Internet by leading UK companies', The European Accounting Review, 8(2), pp.321-333.

Cyert, R.M. \& Ijiri, Y. (1974). 'Problems of implementing the Trueblood objectives report', Journal of Accounting Research, Supplement, pp.29-45.

Deegan, C. \& Rankin, M. (1999). 'The environmental reporting expectations gap: Australian evidence', British Accounting Review, 31(3), September, pp.313346.

Deller, D., Stubenrath, M. \& Weber, C. (1999). 'A survey on the use of the Internet for investor relations in the USA, the UK and Germany', The European Accounting Review, 8(2), pp.351-364.

DTI (1999). Company General Meetings and Shareholder Communication, Consultation Document, London.

(2000). Modern Company Law for a Competitive Economy: Developing the Framework, Consultation Document, March, London, Company Law Review Steering Group.

(2001). Modern Company Law for a Competitive Economy: Final Report, Volume 1, July, London, Company Law Review Steering Group.

(2002). Modernising Company Law, draft Companies Bill, Department for Trade and Industry, London.

Elliott, R.K. (1992), 'The third wave breaks on the shores of accounting', Accounting Horizons, 6(2), June, pp.61-85.

(1994). 'Confronting the future: choices for the attest function', Accounting Horizons, 8(3), September, pp.106-124.

(2001). ' $21^{\text {st }}$ century assurance', Address to the AAA Auditing Section Midyear Meeting, http://raw.rutgers.edu/raw/aaa/audit/ [visited $28^{\text {th }}$ February 2001].

Elliott, R.K. \& Jacobson, P.D. (1994). 'Costs and benefits of business information disclosure', Accounting Horizons, 8(4), December, pp.80-96.

FASB (1998). http://www.rutgers.edu/Accounting/raw/fasb/fauxcom, Norwalk, CT, Financial Accounting Standards Board [visited 24 August 1998]. 
(2000). http://www.rutgers.edu/Accounting/raw/fasb/brrppg.html, Electronic Distribution of Business Reporting Information, Norwalk, CT, Financial Accounting Standards Board [visited 22 March 2000].

FASB (2001). Business and financial reporting, challenges from the new economy Special Report, Norwalk, CT, Financial Accounting Standards Board.

Financial Director (2000). 'Playing FTSE over the web', November, pp.57-64.

FRC (2001). 2000 Annual Review, London, Financial Reporting Council.

Gowthorpe, C. \& Amat, O. (1999). 'External reporting of accounting and financial information via the Internet in Spain', The European Accounting Review, 8(2), pp.365-371.

Hedlin, P. (1999). 'The Internet as a vehicle for investor information: the Swedish case', European Accounting Review, 8(2), pp.373-381.

Hermanson, H. M. (2000). 'An analysis of the demand for reporting on internal control', Accounting Horizons, 14(3), September, pp.325-341.

Holland, J. (1998a). 'Private disclosure and financial reporting', Accounting and Business Research, 28(4), Autumn, pp.255-269.

Holland, J. (1998b). 'Private voluntary disclosure, financial intermediation and market efficiency', Journal of Business Finance and Accounting, 25(1/2), January/March, pp.29-68.

Hussey, R. \& Gulliford, J. (1998). 'Regulating financial reporting on the Internet', Journal of Financial Regulation \& Compliance, 6(1), pp.21-25.

Hussey, R., Gulliford, J. \& Lymer, A. (1998). Corporate Communication: Financial Reporting on the Internet, London, Deloitte and Touche.

Hussey, R. \& Sowinska, M. (1999). 'The risks of financial reports on the Internet', Accounting \& Business, March, pp.18-19.

IASC (1999). Business Reporting on the Internet, Discussion Paper prepared by Lymer, A., Debreceny, R., Gray, G.L. \& Rahman, A., November, London, International Accounting Standards Committee.

ICAS (1999). Business Reporting: The Inevitable Change?, Beattie, V. (ed.), Edinburgh, Institute of Chartered Accountants of Scotland.

ICAEW (1998). The $21^{\text {st }}$ Century Annual Report, Papers from a conference held on the $11^{\text {th }}$ September, London, Institute of Chartered Accountants in England and Wales.

IFAC (2002). Financial Reporting on the Internet, Staff Paper, New York, NY, International Federation of Accountants. 
Investor Relations Society (1998). Annual Reports and the Internet, London, Investor Relations Society.

Jensen, R.E. \& Xiao, J.Z. (2001). 'Customized financial reporting, networked databases, and distributed file sharing', Accounting Horizons, 15(3), September, pp.209-222.

Jonas, G.J. \& Young, S.J. (1998). 'Bridging the gap- who can bring a user focus to business reporting?', Accounting Horizons, 12(2), June, pp.154-159.

Jones, M., Xiao, J. \& Lymer, A. (2001). Trends in Internet Financial Reporting, London, Institute of Chartered Accountants in England and Wales.

Lev, B. (2000). Intangibles Management, Measurement, and Reporting. Washington DC, Brookings Institution Press.

Louwers, T.J., Pasewark, W.R. \& Typpo, E.W. (1996). 'The Internet: changing the way corporations tell their story', CPA Journal, 66(11), pp. 24-28.

Lymer, A. \& Tallberg, A. (1997). 'Corporate reporting and the Internet: a survey and commentary on the use of the WWW in corporate reporting in the UK and Finland', paper presented at the $20^{\text {th }}$ Annual Congress of the European Accounting Association, Graz, Austria, April http://www.summa.org.uk/SUMMA/corp/papers/papers.html [visited 30 October 1998].

Mahajahan, V., Mueller, E. \& Bass, F. (1990). 'New product diffusion models in marketing: a review and direction for research', Journal of Marketing, January, pp.1-26.

Marston, C. \& Leow, C.Y. (1998). 'Financial reporting on the Internet by leading UK companies', EAA conference paper, available at http://www.summa.org.uk/SUMMA/corp/papers/marston/marston.html

McQuail, D. (1997). Audience Analysis, Thousand Oaks, CA: Sage Publications, Inc.

Milne, M.J. \& Chan, C.C.C. (1999). 'Narrative corporate social disclosures: how much of a difference do they make to investment decision-making?', British Accounting Review, 31(4), December, pp.439-457.

Moore, G. (1995). Crossing the Chasm, First paperback edition, New York, NY, HarperBusiness.

Nordberg, D. (1999). Shareholder Communication: The Next Wave, Centre for Business Performance, London, Institute of Chartered Accountants in England and Wales.

Oppenheim, A.N. (1966). Questionnaire Design and Attitude Measurement, Heinemann. 
Petravick, S. \& Gillett, J.W. (1998). 'Distributing earnings reports on the Internet', Management Accounting (USA), 80(4), pp.54-56.

Pirchegger, B. \& Wagenhofer, A. (1999). 'Financial information on the Internet: a survey of the homepages of Austrian companies', The European Accounting Review, 8(2), pp.383-395.

ProShare (1999). Managing Relationships with Private Investors, London, ProShare.

Richardson, V. J. \& Scholz, S. (2000). 'Corporate reporting and the Internet: vision, reality, and intervening obstacles', Pacific Accounting Review, 11(2), pp153159.

Romain, G. (2000). 'Legislation in moderation', Accountancy, December, p.92.

Sabey, S. (1999). 'Establishing how the investment community is using the web: understanding investment needs to ensure successful online communication', Presentation to the Online Investor Relations Conference, $29^{\text {th }}-30^{\text {th }}$ November, London.

SAS (1990). SAS/STAT User's Guide, Version 6, $4^{\text {th }}$ ed., Cary, NC, SAS Institute Inc.

Schipper, K. (1991). 'Commentary on analysts' forecasts', Accounting Horizons, 5(4), December, pp.105-121.

(1994). 'Academic accounting research and the standard-setting process', Accounting Horizons, 8(4), December, pp.61-73.

Siegel, S. \& Castellan, N.J. (1988). Nonparametric Statistics for the Behavioral Sciences, $2^{\text {nd }}$ ed., Singapore, McGraw-Hill.

Taylor, S. (1998). Web Sites - A Missed Opportunity?, Business Briefing, London, Institute of Chartered Accountants in England and Wales.

Thomas, C.W., Davis, C.E. \& Seaman, S.L. (1998). 'Quality review, continuing professional education, experience and substandard performance: an empirical study', Accounting Horizons, 12(4), December, pp.340-362.

Thompson, G. (1996). 'Communications assets in the information age: the impact of technology on corporate communications', Corporate Communications: An International Journal, 1(3), pp.8-10.

Trites, G. (1999a). The Impact of Technology on Financial and Business Reporting, Toronto, Canadian Institute of Chartered Accountants.

(1999b). 'Democratising disclosure', CA Magazine (Canadian), October, p.47. 
Viator, R.E. (1999). 'An analysis of formal mentoring programs and perceived barriers to obtaining a mentor at large public accounting firms'. Accounting Horizons, 13(1), March, pp.37-53.

Wallace, R.S.O. \& Mellor, C.J. (1988). 'Nonresponse bias in mail accounting surveys: a pedagogical note', British Accounting Review, 20(2), August, pp.131-139.

\& Cooke, T.E. (1990). 'Nonresponse bias in mail accounting surveys: a pedagogical extension', British Accounting Review, 22(3), September, pp.283-288.

Wallman, S.M.H. (1995). 'The future of accounting and disclosure in an evolving world: the need for dramatic change', Accounting Horizons, 9(3), September, pp.81-91.

(1997). 'The future of accounting and financial reporting, part IV: “access" accounting', Accounting Horizons, 11(2), June, pp.103-116.

Walsh, S.T. \& White, C.G. (2000). 'Congress's goal of increasing electronic filing: an assessment based on the technology-adoption literature', Accounting Horizons, 14(4), December, pp.403-425.

Watts, R.L. \& Zimmerman, J.L. (1986). Positive Accounting Theory, Englewood Cliffs, NJ, Prentice-Hall International.

Weetman, P., Davie, E.S. \& Collins, W. (1996). 'Lobbying on accounting issues: preparer/user imbalance in the case of the Operating and Financial Review', Accounting, Auditing \& Accountability Journal, 9(1), pp.59-76.

XBRL (2000). http://www.xfrml.org and related sites [visited 5 April 2000 and 1 February 2001].

Xiao, Z., Jones, M. \& Lymer, A. (2002). 'Immediate trends in Internet reporting', European Accounting Review, 11(2), pp.245-275.

Yap, C. (1997). 'Users' perceptions of the need for cash flow statements - Australian evidence', European Accounting Review, 6(4), pp.653-672. 
Figure 1: Key parties in the reporting process and conflicts of interest

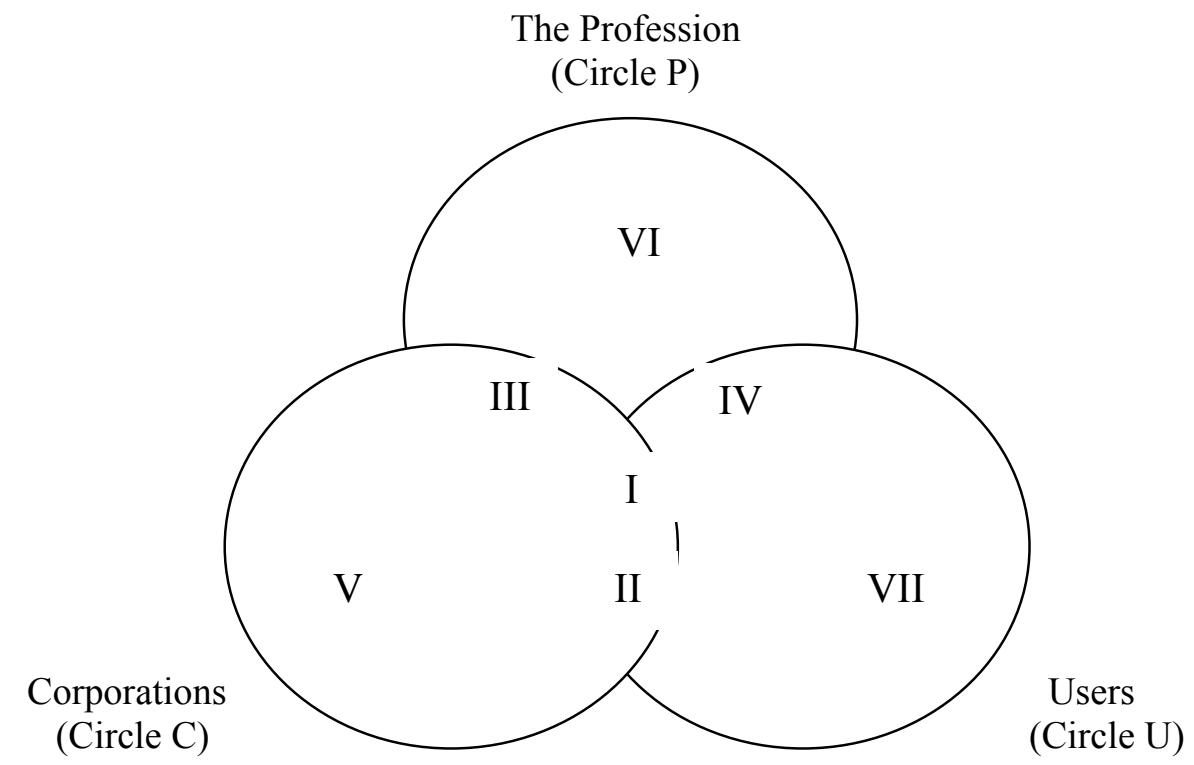

Reprinted with permission. Cyert, R M and Ijiri Y, (1974), 'Problems of implementing the Trueblood objectives report', Journal of Accounting Research, Supplement diagram 1, p30. (C) Institute of Professional Accounting, 1975) 
Table 1 Summary of recent prior studies of company web reporting practices

\begin{tabular}{|c|c|c|c|c|c|}
\hline \multirow[t]{2}{*}{ Study } & \multirow[t]{2}{*}{ Details of sample(s) } & \multirow{2}{*}{$\begin{array}{l}\text { Existence of } \\
\text { corporate } \\
\text { website }\end{array}$} & \multirow{2}{*}{$\begin{array}{l}\text { Frequency and type of } \\
\text { financial information } \\
\text { provision }\end{array}$} & \multicolumn{2}{|c|}{ Web features } \\
\hline & & & & Hyperlinks & Formats \\
\hline Deller et al. (1999) & $\begin{array}{l}\text { Top } 100 \text { companies in: } \\
\text { US } \\
\text { UK } \\
\text { Germany; } \\
\text { at January } 1998\end{array}$ & $\begin{array}{l}95 \% \\
85 \% \\
76 \%\end{array}$ & $\begin{array}{l}\text { Balance sheet: P\&L; time } \\
\text { series: } \\
95 \% ; 95 \% ; 95 \% \\
74 \% ; 75 \% ; 28 \% \\
65 \% ; 63 \% ; 21 \%\end{array}$ & $\begin{array}{l}\text { Hyperlinked accounting data: } \\
7 \% \\
38 \% \\
13 \%\end{array}$ & $\begin{array}{l}\text { Financial data in PDF; processable } \\
\text { format: } \\
35 \% ; 13 \% \\
35 \% ; 6 \% \\
17 \% ; 7 \%\end{array}$ \\
\hline FASB (2000) & $\begin{array}{l}\text { Fortune 100; } \\
\text { 30 January } 1999\end{array}$ & $99 \%$ & $\begin{array}{l}\text { Investor relations/financial } \\
\text { information: } 93 \%\end{array}$ & $\begin{array}{c}\text { Direct link from home page to: } \\
\text { investor relations: } 67 \% \\
\text { latest annual report: } 22 \% \\
\text { Hyperlinked table of contents: } 71 \% \\
\text { 'Next' \& 'previous' buttons: } 42 \%\end{array}$ & $\begin{array}{l}\text { Financial statements : } \\
\text { PDF only: } 21 \% ; \\
\text { HTML: } 58 \% \\
\text { wordprocessor: } 12 \% \\
\text { spreadsheet: } 16 \%\end{array}$ \\
\hline $\begin{array}{l}\text { Financial Director } \\
(2000)\end{array}$ & $\begin{array}{l}\text { FTSE 100; } \\
\text { November } 2000\end{array}$ & - & - & - & $\begin{array}{l}\text { In addition to HTML: } \\
\text { PDF: } 94 \% \\
\text { powerpoint: } 24 \% \\
\text { spreadsheet: } 17 \% \\
\text { wordprocessor: } 14 \%\end{array}$ \\
\hline Taylor (1998) & $\begin{array}{l}100 \text { of world's largest } \\
\text { international } \\
\text { companies }\end{array}$ & - & $\begin{array}{l}\text { Annual report: } 83 \% \\
\text { Presentations to analysts: } \\
13 \%\end{array}$ & - & $\begin{array}{l}\text { PDF only: nearly half } \\
\text { HTML: just over half }\end{array}$ \\
\hline IASC (1999) & $\begin{array}{l}30 \text { largest listed } \\
\text { companies from } 22 \\
\text { countries }-660 \text { in total }\end{array}$ & $84 \%$ & $\begin{array}{l}\text { Some form of financial } \\
\text { disclosure: } 62 \%\end{array}$ & - & - \\
\hline
\end{tabular}


Table 2 Sample groups and response rates

\begin{tabular}{|l|c|c|c|c|}
\hline \multicolumn{1}{|c|}{ Group } & $\begin{array}{c}\text { No. in } \\
\text { sample }\end{array}$ & $\begin{array}{c}\text { No. } \\
\text { responding }\end{array}$ & $\begin{array}{c}\text { Response } \\
\text { rate } \%\end{array}$ & $\begin{array}{c}\text { Code } \\
\text { used }\end{array}$ \\
\hline Expert users: & & & & \\
\hline Investment analysts & 410 & 104 & 25 & IA \\
\hline Fund managers & 99 & 27 & 27 & FM \\
\hline Corporate lenders & 79 & 28 & 35 & CL \\
\hline Sub-total & $\mathbf{5 8 8}$ & $\mathbf{1 5 9}$ & $\mathbf{2 7}$ & \\
\hline Non-expert users: private shareholders & 543 & 235 & 43 & PS \\
\hline Preparers: finance directors & 421 & 83 & 20 & FD \\
\hline Auditors: audit partners & 93 & 61 & 66 & AP \\
\hline Total & $\mathbf{1 6 4 5}$ & $\mathbf{5 3 8}$ & $\mathbf{3 3}$ & \\
\hline
\end{tabular}


Table 3 Frequency of use of Internet by respondents

\begin{tabular}{|l|l|l|l|l|}
\hline & \multicolumn{4}{|c|}{ Percentage of respondents } \\
\hline & Never & Rarely & $\begin{array}{c}\text { About once } \\
\text { weekly }\end{array}$ & $\begin{array}{c}\text { Almost } \\
\text { daily }\end{array}$ \\
\hline Total & 12 & 9 & 19 & 60 \\
\hline Primary group & - & 3 & 13 & 84 \\
\hline Expert users & -57 & 12 & 20 & 41 \\
\hline Private shareholders & 27 & 11 & 22 & 66 \\
\hline Finance directors & 1 & 7 & 31 & 59 \\
\hline Audit partners & 3 & 7 & 11 & 86 \\
\hline Expert users & - & 3 & 4 & 92 \\
\hline Investment analysts & - & 4 & 28 & 68 \\
\hline Fund managers & - & 4 & \\
\hline Corporate lenders & - &
\end{tabular}


Table 4 Attitudes to proposals re scope, structure and frequency of web-based reporting packages

\begin{tabular}{|c|c|c|c|c|c|c|c|c|c|c|c|}
\hline \multirow{3}{*}{$\begin{array}{c}\text { Question } \\
\text { (abbreviated) }\end{array}$} & \multicolumn{8}{|c|}{ Mean (std. dev. below) ${ }^{1,2,3} R Q 1(R Q 2)$} & \multicolumn{3}{|c|}{$\begin{array}{l}\text { Sig diff. between } \\
\text { groups }{ }^{4,5}\end{array}$} \\
\hline & \multirow[b]{2}{*}{ Total } & \multicolumn{4}{|c|}{ Primary groups $(\mathbf{P})$} & \multicolumn{3}{|c|}{ Expert groups (E) } & \multirow{2}{*}{$\begin{array}{c}R Q 3 \\
\mathbf{P}^{6}\end{array}$} & \multirow{2}{*}{$\begin{array}{c}R Q 4 \\
\mathrm{E}\end{array}$} & \multirow{2}{*}{$\frac{R Q 5}{\text { FD }^{6}}$} \\
\hline & & $\mathbf{E U}$ & PS & FD & AP & IA & FM & $\mathbf{C L}$ & & & \\
\hline \multicolumn{12}{|l|}{ Companies be required to: } \\
\hline $\begin{array}{l}\text { 1. make available key information that it uses to manage the company (subject to } \\
\text { legitimate concerns) }\end{array}$ & $\begin{array}{l}2.61^{* * *} \\
(1.26)\end{array}$ & $\begin{array}{l}2.37^{* * *} \\
(1.17)\end{array}$ & $\begin{array}{l}2.42^{* * *} \\
(1.18)\end{array}$ & $\begin{array}{l}3.29^{*} \\
(1.26)\end{array}$ & $\begin{array}{l}3.02 \\
(1.31)\end{array}$ & $\begin{array}{l}2.32^{* * *} \\
(1.18)\end{array}$ & $\begin{array}{l}2.56^{*} \\
(1.09)\end{array}$ & $\begin{array}{l}2.34^{*} \\
(1.25)\end{array}$ & 0.001 & NS & NS \\
\hline $\begin{array}{l}\text { 2. layer information to avoid information overload, while providing the detail } \\
\text { desired by many }\end{array}$ & $\begin{array}{l}1.99^{* * *} \\
(0.88)\end{array}$ & $\begin{array}{l}1.86^{* * *} \\
(0.80)\end{array}$ & $\begin{array}{l}1.93^{* * * *} \\
(0.85) \\
\end{array}$ & $\begin{array}{l}2.38^{* * *} \\
(1.08)\end{array}$ & $\begin{array}{l}2.02^{* * *} \\
(0.71)\end{array}$ & $\begin{array}{l}1.86 \\
(0.75)\end{array}$ & $\begin{array}{l}2.00^{* * * *} \\
(0.98)\end{array}$ & $\begin{array}{l}1.71^{* * *} \\
(0.76)\end{array}$ & 0.001 & NS & 0.05 \\
\hline $\begin{array}{l}\text { 3. maintain a facility on their website for free search, allowing users to retain } \\
\text { control over the search and selection process }\end{array}$ & $\begin{array}{l}2.35^{* * *} \\
(1.00)\end{array}$ & $\begin{array}{l}2.27^{* * *} \\
(0.96)\end{array}$ & $\begin{array}{l}2.08^{* * * *} \\
(0.95)\end{array}$ & $\begin{array}{l}3.03 \\
(1.03)\end{array}$ & $\begin{array}{l}2.55^{* * *} \\
(0.77)\end{array}$ & $\begin{array}{l}2.13^{* * *} \\
(0.97)\end{array}$ & $\begin{array}{l}2.54^{* *} \\
(0.81)\end{array}$ & $\begin{array}{l}2.56^{*} \\
(0.97)\end{array}$ & 0.001 & 0.05 & NS \\
\hline $\begin{array}{l}\text { 4. provide a range of pre-packaged information, based on a standardised } \\
\text { template for each group of users, specified by an external regulatory body }\end{array}$ & $\begin{array}{l}2.56^{* * *} \\
(1.06)\end{array}$ & $\begin{array}{l}2.51^{* * *} \\
(0.99)\end{array}$ & $\begin{array}{l}2.29^{* * *} \\
(1.01)\end{array}$ & $\begin{array}{l}3.06 \\
(1.05)\end{array}$ & $\begin{array}{l}2.92 \\
(1.10)\end{array}$ & $\begin{array}{l}2.52^{* * *} \\
(1.00)\end{array}$ & $\begin{array}{l}2.74 \\
(1.02)\end{array}$ & $\begin{array}{l}2.21^{* * *} \\
(0.88)\end{array}$ & 0.001 & NS & NS \\
\hline $\begin{array}{l}\text { 5(i). extend access to general company meetings with financial } \\
\text { analysts/institutional shareholders by placing records (i.e. presentation packs } \\
\text { and slides) on website, to reduce unfair advantage }\end{array}$ & $\begin{array}{l}1.94^{* * *} \\
(0.94)\end{array}$ & $\begin{array}{l}1.83^{* * *} \\
(0.85)\end{array}$ & $\begin{array}{l}1.73^{* * *} \\
(0.86)\end{array}$ & $\begin{array}{l}2.61^{* *} \\
(1.15)\end{array}$ & $\begin{array}{l}2.00^{* * *} \\
(0.71)\end{array}$ & $\begin{array}{l}1.75^{* * *} \\
(0.82)\end{array}$ & $\begin{array}{l}1.89^{* * *} \\
(0.75)\end{array}$ & $\begin{array}{l}2.11^{* * *} \\
(0.99)\end{array}$ & 0.001 & NS & 0.05 \\
\hline $\begin{array}{l}\text { 5(ii). extend access to general company meetings with financial } \\
\text { analysts/institutional shareholders by archiving an audio-visual record on } \\
\text { website, to reduce unfair advantage }\end{array}$ & $\begin{array}{l}2.38^{* * *} \\
(1.07)\end{array}$ & $\begin{array}{l}2.19^{* * *} \\
(1.01)\end{array}$ & $\begin{array}{l}2.17^{* * * *} \\
(0.98)\end{array}$ & $\begin{array}{l}3.10 \\
(1.14)\end{array}$ & $\begin{array}{l}2.62^{* *} \\
(0.96)\end{array}$ & $\begin{array}{l}2.10^{* * *} \\
(0.99)\end{array}$ & $\begin{array}{l}2.19^{* * *} \\
(0.80)\end{array}$ & $\begin{array}{l}2.56 \\
(1.22)\end{array}$ & 0.001 & NS & 0.01 \\
\hline $\begin{array}{l}\text { 5(iii). extend access to general company meetings with financial } \\
\text { analysts/institutional shareholders by broadcasting live via satellite } \\
\text { television channel or video webcast, to reduce unfair advantage }\end{array}$ & $\begin{array}{l}3.13^{* *} \\
(1.05)\end{array}$ & $\begin{array}{l}2.93 \\
(1.09)\end{array}$ & $\begin{array}{l}3.00 \\
(0.98)\end{array}$ & $\begin{array}{l}3.62^{* * *} \\
(1.10)\end{array}$ & $\begin{array}{l}3.37^{* *} \\
(0.88)\end{array}$ & $\begin{array}{l}2.90 \\
(1.12)\end{array}$ & $\begin{array}{l}2.72 \\
(1.02)\end{array}$ & $\begin{array}{l}3.26 \\
(0.98)\end{array}$ & 0.001 & NS & 0.01 \\
\hline $\begin{array}{l}\text { 6. extend access to one-to-one meetings by placing detailed minutes on website, } \\
\text { to reduce unfair advantage }\end{array}$ & $\begin{array}{l}3.03 \\
(1.24)\end{array}$ & $\begin{array}{l}3.21^{*} \\
(1.24)\end{array}$ & $\begin{array}{l}2.51^{* * *} \\
(1.14)\end{array}$ & $\begin{array}{l}3.92^{* * *} \\
(0.93)\end{array}$ & $\begin{array}{l}3.08 \\
(1.08)\end{array}$ & $\begin{array}{l}3.23 \\
(1.29)\end{array}$ & $\begin{array}{l}3.38 \\
(1.13)\end{array}$ & $\begin{array}{l}3.00 \\
(1.19)\end{array}$ & 0.001 & NS & NS \\
\hline 7. teleconference (i.e. webcast) company AGMs to allow wider access & $\begin{array}{l}2.60^{* * *} \\
(1.00)\end{array}$ & $\begin{array}{l}2.40^{* * * *} \\
(0.92)\end{array}$ & $\begin{array}{l}2.46^{* * *} \\
(0.96)\end{array}$ & $\begin{array}{l}3.28^{*} \\
(1.02)\end{array}$ & $\begin{array}{l}2.72^{*} \\
(0.93)\end{array}$ & $\begin{array}{l}2.33^{* * * *} \\
(0.95)\end{array}$ & $\begin{array}{l}2.31^{* * * *} \\
(0.79)\end{array}$ & $\begin{array}{l}2.75 \\
(0.84)\end{array}$ & 0.001 & NS & 0.05 \\
\hline $\begin{array}{l}\text { 8. replace company AGMs by a facility for online questioning of management } \\
\text { by users and conduct voting online }\end{array}$ & $\begin{array}{l}3.54^{* * * *} \\
(1.11)\end{array}$ & $\begin{array}{l}3.38 \\
(1.06)\end{array}$ & $\begin{array}{l}3.78^{* * * *} \\
(1.16)\end{array}$ & $\begin{array}{l}3.41^{* * *} \\
(1.02)\end{array}$ & $\begin{array}{l}3.30^{*} \\
(1.04)\end{array}$ & $\begin{array}{l}3.44^{* * * *} \\
(1.09)\end{array}$ & $\begin{array}{l}3.16 \\
(0.85)\end{array}$ & $\begin{array}{l}3.33 \\
(1.11)\end{array}$ & 0.001 & NS & NS \\
\hline $\begin{array}{l}\text { 9. update business reporting information on websites periodically (e.g. quarterly } \\
\text { or monthly), not continuously }\end{array}$ & $\begin{array}{l}2.53^{* * *} \\
(1.05)\end{array}$ & $\begin{array}{l}2.53^{* * *} \\
(1.04)\end{array}$ & $\begin{array}{l}2.59^{* * * *} \\
(1.11)\end{array}$ & $\begin{array}{l}2.54^{* * *} \\
(1.07)\end{array}$ & $\begin{array}{l}2.31^{* * *} \\
(0.85)\end{array}$ & $\begin{array}{l}2.51^{* * *} \\
(1.03)\end{array}$ & $\begin{array}{l}2.54^{*} \\
(0.99)\end{array}$ & $\begin{array}{l}2.61 \\
(1.17)\end{array}$ & NS & NS & NS \\
\hline $\begin{array}{l}\text { 10. distinguish clearly information that is continuously updated from more stable } \\
\text { information that is updated only periodically }\end{array}$ & $\begin{array}{l}1.96^{* * *} \\
(0.71)\end{array}$ & $\begin{array}{l}1.97^{* * *} \\
(0.64)\end{array}$ & $\begin{array}{l}1.89^{* * * *} \\
(0.73)\end{array}$ & $\begin{array}{l}2.19^{* * *} \\
(0.84)\end{array}$ & $\begin{array}{l}1.87^{* * *} \\
(0.59)\end{array}$ & $\begin{array}{l}1.91^{* * *} \\
(0.67)\end{array}$ & $\begin{array}{l}2.23^{* * *} \\
(0.59)\end{array}$ & $\begin{array}{l}1.89^{* * *} \\
(0.57)\end{array}$ & 0.01 & NS & NS \\
\hline
\end{tabular}

Notes: 1 . Response categories are: $1=$ strongly agree; $2=$ agree; $3=$ neutral; $4=$ disagree; and $5=$ strongly disagree.

2. EU = expert users; PS = private shareholders; FD = finance directors; $\mathrm{AP}=$ audit partners; $\mathrm{IA}=$ investment analysts; $\mathrm{FM}=$ fund managers; $\mathrm{CL}=$ corporate lenders.

3. Significance of t-test of whether group response is different from $3=$ neutral: $*, * *, * * *=$ significant at $5 \%, 1 \%$ and $0.1 \%$, respectively.

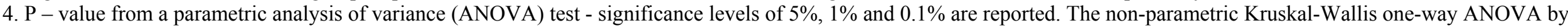
ranks test gave equivalent significant levels in virtually all cases and so are not reported here.

5. $\mathrm{P}=$ primary groups $\mathrm{E}=$ expert user groups; $\mathrm{FD}=$ large vs. small company groups

6. See Table 7 for detail of multiple paired comparisons. 
Table 5 Usefulness of navigation and search aids

\begin{tabular}{|c|c|c|c|c|c|c|c|c|c|c|c|}
\hline \multirow{3}{*}{$\begin{array}{c}\text { Question } \\
\text { (abbreviated) }\end{array}$} & \multicolumn{8}{|c|}{ Mean (std. dev. below) $)^{1,2} R Q 1$ (RQ2) } & \multicolumn{3}{|c|}{$\begin{array}{c}\text { Sig diff. between } \\
\text { groups }^{3,4,5}\end{array}$} \\
\hline & \multirow[b]{2}{*}{ Total } & \multicolumn{4}{|c|}{ Primary groups (P) } & \multicolumn{3}{|c|}{ Expert groups (E) } & \multirow{2}{*}{$\frac{R Q 3}{\mathrm{P}}$} & \multirow{2}{*}{$\frac{R Q 4}{\mathrm{E}}$} & \multirow{2}{*}{$\begin{array}{r}R Q 5 \\
\text { FD } \\
\end{array}$} \\
\hline & & $\mathbf{E U}$ & PS & FD & $\mathbf{A P}$ & IA & FM & CL & & & \\
\hline \multicolumn{12}{|l|}{ Usefulness of feature: } \\
\hline 1. Business reporting information is clearly indexed on the home page & $\begin{array}{l}1.49 \\
(0.65)\end{array}$ & $\begin{array}{l}1.49 \\
(0.61)\end{array}$ & $\begin{array}{l}1.46 \\
(0.68)\end{array}$ & $\begin{array}{l}1.59 \\
(0.69)\end{array}$ & $\begin{array}{l}1.44 \\
(0.59)\end{array}$ & $\begin{array}{l}1.44 \\
(0.59)\end{array}$ & $\begin{array}{l}1.72 \\
(0.68)\end{array}$ & $\begin{array}{l}1.50 \\
(0.58)\end{array}$ & NS & NS & NS \\
\hline 2. A hyperlinked site map or table of contents is available & $\begin{array}{l}1.57 \\
(0.69)\end{array}$ & $\begin{array}{l}1.56 \\
(0.63)\end{array}$ & $\begin{array}{l}1.53 \\
(0.74)\end{array}$ & $\begin{array}{l}1.73 \\
(0.75)\end{array}$ & $\begin{array}{l}1.52 \\
(0.59)\end{array}$ & $\begin{array}{l}1.51 \\
(0.63)\end{array}$ & $\begin{array}{l}1.79 \\
(0.66)\end{array}$ & $\begin{array}{l}1.57 \\
(0.57)\end{array}$ & NS & NS & NS \\
\hline $\begin{array}{l}\text { 3(i). Hyperlinks exist between items in the financial statements and the relevant note } \\
\text { to the accounts }\end{array}$ & $\begin{array}{l}1.66 \\
(0.79)\end{array}$ & $\begin{array}{l}1.53 \\
(0.68)\end{array}$ & $\begin{array}{l}1.67 \\
(0.83)\end{array}$ & $\begin{array}{l}1.84 \\
(0.82)\end{array}$ & $\begin{array}{l}1.74 \\
(0.81)\end{array}$ & $\begin{array}{l}1.50 \\
(0.69)\end{array}$ & $\begin{array}{l}1.71 \\
(0.62)\end{array}$ & $\begin{array}{l}1.46 \\
(0.69)\end{array}$ & 0.05 & NS & NS \\
\hline $\begin{array}{l}\text { 3(ii). Hyperlinks exist between items in the financial statements and the relevant } \\
\text { section of the OFR }\end{array}$ & $\begin{array}{ll}1.86 \\
(0.85)\end{array}$ & $\begin{array}{l}1.80 \\
(0.80)\end{array}$ & $\begin{array}{l}1.86 \\
(0.86)\end{array}$ & $\begin{array}{l}2.11 \\
(0.93)\end{array}$ & $\begin{array}{l}1.72 \\
(0.78)\end{array}$ & $\begin{array}{l}1.77 \\
(0.81)\end{array}$ & $\begin{array}{l}1.96 \\
(0.81)\end{array}$ & $\begin{array}{l}1.79 \\
(0.79)\end{array}$ & 0.05 & NS & NS \\
\hline $\begin{array}{l}\text { 3(iii). Hyperlinks exist between items in the financial statements and the five-year } \\
\text { summary }\end{array}$ & $\begin{array}{l}2.12 \\
(0.99)\end{array}$ & $\begin{array}{l}2.17 \\
(0.92)\end{array}$ & $\begin{array}{l}1.91 \\
(0.97)\end{array}$ & $\begin{array}{l}2.31 \\
(1.04)\end{array}$ & $\begin{array}{l}2.37 \\
(1.10)\end{array}$ & $\begin{array}{l}2.11 \\
(0.94)\end{array}$ & $\begin{array}{l}2.30 \\
(0.76)\end{array}$ & $\begin{array}{l}2.29 \\
(0.98)\end{array}$ & 0.01 & NS & NS \\
\hline 4(i). Hyperlinks exist between the individual notes to the accounts and the OFR & $\begin{array}{l}2.16 \\
(0.97)\end{array}$ & $\begin{array}{l}2.15 \\
(0.94)\end{array}$ & $\begin{array}{l}2.13 \\
(0.97)\end{array}$ & $\begin{array}{l}2.41 \\
(1.00)\end{array}$ & $\begin{array}{l}1.98 \\
(0.94)\end{array}$ & $\begin{array}{l}2.09 \\
(0.92)\end{array}$ & $\begin{array}{l}2.21 \\
(0.93)\end{array}$ & $\begin{array}{l}2.32 \\
(1.06)\end{array}$ & NS & NS & NS \\
\hline 4(ii). Hyperlinks exist between the OFR and relevant forward-looking information & \begin{tabular}{|l|}
2.13 \\
$(0.95)$
\end{tabular} & $\begin{array}{l}2.11 \\
(0.91)\end{array}$ & $\begin{array}{l}2.07 \\
(0.96)\end{array}$ & $\begin{array}{l}2.44 \\
(0.99)\end{array}$ & $\begin{array}{l}1.93 \\
(0.89)\end{array}$ & $\begin{array}{l}2.08 \\
(0.94)\end{array}$ & $\begin{array}{l}2.13 \\
(0.85)\end{array}$ & $\begin{array}{l}2.18 \\
(0.90)\end{array}$ & 0.05 & NS & NS \\
\hline 4(iii). Hyperlinks exist between the OFR and relevant company background & $\begin{array}{l}2.30 \\
(0.97)\end{array}$ & $\begin{array}{l}2.32 \\
(0.94)\end{array}$ & $\begin{array}{l}2.22 \\
(0.98)\end{array}$ & $\begin{array}{l}2.54 \\
(1.03)\end{array}$ & $\begin{array}{l}2.20 \\
(0.93)\end{array}$ & $\begin{array}{l}2.29 \\
(0.96)\end{array}$ & $\begin{array}{l}2.33 \\
(0.70)\end{array}$ & $\begin{array}{l}2.39 \\
(1.07)\end{array}$ & NS & NS & NS \\
\hline $\begin{array}{l}\text { 5. The facility to 'point and click' on financial items to get a time series graph of the } \\
\text { item }\end{array}$ & $\begin{array}{l}2.09 \\
(0.91)\end{array}$ & $\begin{array}{l}2.08 \\
(0.88)\end{array}$ & $\begin{array}{l}1.86 \\
(0.86)\end{array}$ & $\begin{array}{l}2.50 \\
(0.93)\end{array}$ & $\begin{array}{l}2.30 \\
(0.87)\end{array}$ & $\begin{array}{l}2.03 \\
(0.95)\end{array}$ & $\begin{array}{l}2.24 \\
(0.83)\end{array}$ & $\begin{array}{l}2.14 \\
(0.65)\end{array}$ & 0.001 & NS & 0.05 \\
\hline 6. 'Next' and 'previous' buttons at the bottom of each page & $\begin{array}{l}1.77 \\
(0.82)\end{array}$ & $\begin{array}{l}1.81 \\
(0.83)\end{array}$ & $\begin{array}{l}1.74 \\
(0.85)\end{array}$ & $\begin{array}{l}1.72 \\
(0.73)\end{array}$ & $\begin{array}{l}1.82 \\
(0.81)\end{array}$ & $\begin{array}{l}1.70 \\
(0.78)\end{array}$ & $\begin{array}{l}2.12 \\
(0.88)\end{array}$ & $\begin{array}{l}1.92 \\
(0.92)\end{array}$ & NS & NS & NS \\
\hline 7. Users can sign up for e-mail alerts & $\begin{array}{l}1.79 \\
(0.84)\end{array}$ & $\begin{array}{l}1.84 \\
(0.88)\end{array}$ & $\begin{array}{l}1.74 \\
(0.87)\end{array}$ & $\begin{array}{l}1.87 \\
(0.84)\end{array}$ & $\begin{array}{l}1.77 \\
(0.67)\end{array}$ & $\begin{array}{l}1.73 \\
(0.86)\end{array}$ & $\begin{array}{l}2.16 \\
(0.90)\end{array}$ & $\begin{array}{l}1.93 \\
(0.86)\end{array}$ & NS & NS & NS \\
\hline
\end{tabular}

Notes: 1 . Response categories are: $1=$ very useful; $2=$ useful; $3=$ fairly useful; $4=$ of little use; and $5=$ not useful at all

$\overline{2 .} \mathrm{EU}=$ expert users; $\mathrm{PS}=$ private shareholders; $\mathrm{FD}=$ finance directors; $\mathrm{AP}=$ audit partners; $\mathrm{IA}=$ investment analysts; $\mathrm{FM}=$ fund managers; $\mathrm{CL}=$ corporate lenders.

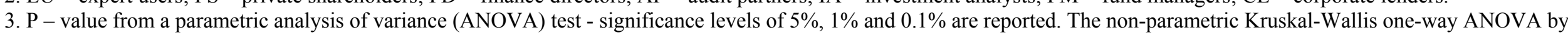
ranks test gave equivalent significant levels in virtually all cases and so are not reported here.

4. $\mathrm{P}=$ primary groups; $\mathrm{E}=$ expert user groups; FD indicates large vs. small company groups.

5. See Table 7 for detail of multiple paired comparisons. 
Table 6 Portability of information - file formats

\begin{tabular}{|c|c|c|c|c|c|c|c|c|c|c|c|}
\hline \multirow{3}{*}{$\begin{array}{c}\text { Question } \\
\text { (abbreviated) }\end{array}$} & \multicolumn{8}{|c|}{ Mean (std. dev. below) ${ }^{1,2} R Q 1(R Q 2)$} & \multicolumn{3}{|c|}{$\begin{array}{c}\text { Sig diff. between } \\
\text { groups }^{3,4,5}\end{array}$} \\
\hline & \multirow[b]{2}{*}{ Total } & \multicolumn{4}{|c|}{ Primary groups (P) } & \multicolumn{3}{|c|}{ Expert groups (E) } & \multirow{2}{*}{\begin{tabular}{|c|}
$R Q 3$ \\
$P$ \\
\end{tabular}} & \multirow{2}{*}{\begin{tabular}{|c|}
$R Q 4$ \\
$\mathrm{E}$
\end{tabular}} & \multirow{2}{*}{$\begin{array}{r}R Q 5 \\
\text { FD } \\
\end{array}$} \\
\hline & & $\mathbf{E U}$ & PS & FD & $\mathbf{A P}$ & IA & FM & CL & & & \\
\hline \multicolumn{12}{|l|}{ Usefulness of file format/ feature: } \\
\hline 1. HTML & $\begin{array}{l}2.50 \\
(1.03) \\
\end{array}$ & $\begin{array}{l}2.68 \\
(1.08)\end{array}$ & $\begin{array}{l}2.30 \\
(1.06) \\
\end{array}$ & $\begin{array}{l}2.51 \\
(0.91) \\
\end{array}$ & $\begin{array}{l}2.55 \\
(0.87) \\
\end{array}$ & $\begin{array}{l}2.65 \\
(1.17) \\
\end{array}$ & $\begin{array}{l}2.95 \\
(0.78) \\
\end{array}$ & $\begin{array}{l}2.58 \\
(0.93) \\
\end{array}$ & 0.05 & NS & NS \\
\hline 2. PDF & $\begin{array}{l}2.51 \\
(0.99)\end{array}$ & $\begin{array}{l}2.32 \\
(0.93)\end{array}$ & $\begin{array}{l}2.66 \\
(1.11)\end{array}$ & $\begin{array}{l}2.46 \\
(0.89)\end{array}$ & $\begin{array}{l}2.65 \\
(0.86)\end{array}$ & $\begin{array}{l}2.21 \\
(0.95)\end{array}$ & $\begin{array}{l}2.50 \\
(1.04)\end{array}$ & $\begin{array}{l}2.62 \\
(0.67)\end{array}$ & 0.05 & NS & NS \\
\hline 3. word-processed & $\begin{array}{l}2.31 \\
(1.00)\end{array}$ & $\begin{array}{l}2.24 \\
(0.94)\end{array}$ & $\begin{array}{l}2.31 \\
(1.09)\end{array}$ & $\begin{array}{l}2.43 \\
(1.00)\end{array}$ & $\begin{array}{l}2.37 \\
(0.88)\end{array}$ & $\begin{array}{l}2.21 \\
(0.97)\end{array}$ & $\begin{array}{l}2.40 \\
(0.99)\end{array}$ & $\begin{array}{l}2.22 \\
(0.85)\end{array}$ & NS & NS & NS \\
\hline 4. spreadsheet & $\begin{array}{l}2.21 \\
(1.03)\end{array}$ & $\begin{array}{l}1.92 \\
(0.87)\end{array}$ & $\begin{array}{l}2.31 \\
(1.12)\end{array}$ & $\begin{array}{l}2.44 \\
(1.09)\end{array}$ & $\begin{array}{l}2.36 \\
(0.92)\end{array}$ & $\begin{array}{l}1.88 \\
(0.88)\end{array}$ & $\begin{array}{l}2.18 \\
(1.00)\end{array}$ & $\begin{array}{l}1.85 \\
(0.72\end{array}$ & 0.001 & NS & NS \\
\hline 5. XBRL & $\begin{array}{l}2.41 \\
(1.05)\end{array}$ & $\begin{array}{l}2.20 \\
(0.93)\end{array}$ & $\begin{array}{l}2.61 \\
(1.17)\end{array}$ & $\begin{array}{l}2.46 \\
(1.04)\end{array}$ & $\begin{array}{l}2.30 \\
(0.89)\end{array}$ & $\begin{array}{l}2.18 \\
(1.01)\end{array}$ & $\begin{array}{l}2.45 \\
(0.69)\end{array}$ & $\begin{array}{l}2.12 \\
(0.78)\end{array}$ & 0.05 & NS & NS \\
\hline 6. type tags allow automatic inter-company comparisons & $\begin{array}{l}2.12 \\
(1.03)\end{array}$ & $\begin{array}{l}1.90 \\
(0.86)\end{array}$ & $\begin{array}{l}2.26 \\
(1.14)\end{array}$ & $\begin{array}{l}2.34 \\
(1.03)\end{array}$ & $\begin{array}{l}1.96 \\
(0.97)\end{array}$ & $\begin{array}{l}1.78 \\
(0.83)\end{array}$ & $\begin{array}{l}2.39 \\
(0.91)\end{array}$ & $\begin{array}{l}1.92 \\
(0.83)\end{array}$ & 0.01 & 0.05 & NS \\
\hline
\end{tabular}

Notes: 1 . Response categories are: $1=$ very useful; $2=$ useful; $3=$ fairly useful; $4=$ of little use; and $5=$ not useful at all.

2. $\mathrm{EU}=$ expert users; $\mathrm{PS}=$ private shareholders; $\mathrm{FD}=$ finance directors; $\mathrm{AP}=$ audit partners; $\mathrm{IA}=$ investment analysts; $\mathrm{FM}=$ fund managers; $\mathrm{CL}=$ corporate lenders.

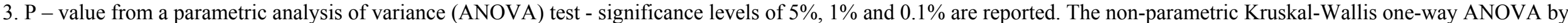
ranks test gave equivalent significant levels in virtually all cases and so are not reported here.

4. $\mathrm{P}=$ primary groups; $\mathrm{E}=$ expert user groups; FD indicates large vs. small company groups.

5. See Table 7 for detail of multiple paired comparisons. 
Table 7 Groups' ranking of five file formats

Panel A: Expert users

\begin{tabular}{|l|l|}
\hline File format & Ranking $^{\mathbf{1 , 2}}$ \\
\hline Spreadsheet & 1 \\
\hline XBRL & 2 \\
\hline Word-processed & 2 \\
\hline PDF & 2 \\
\hline HTML & 3 \\
\hline
\end{tabular}

\begin{tabular}{|c|c|}
\hline \multicolumn{2}{|c|}{ Panel B: Private shareholders } \\
\hline File format & Ranking $^{1,2}$ \\
\hline HTML & 17 \\
\hline Word-processed & 1 \\
\hline Spreadsheet & $1]$ \\
\hline XBRL & 27 \\
\hline PDF & 2 \\
\hline
\end{tabular}

Panel C: Finance directors

\begin{tabular}{|l|l|l|}
\hline File format & \multicolumn{2}{|l|}{ Ranking $^{\mathbf{1 , 2}}$} \\
\hline Word-processed & 1 \\
\hline Spreadsheet & 1 & \\
\hline XBRL & 1 & \\
\hline PDF & 1 & \\
\hline HTML & 1 & \multicolumn{1}{|l|}{} \\
\hline
\end{tabular}

Panel D: Audit partners

$\left.\begin{array}{|l|l|}\hline \text { File format } & \text { Ranking }^{\mathbf{1 , 2}} \\ \hline \text { XBRL } & 1 \\ \hline \text { Spreadsheet } & 1 \\ \hline \text { Word-processed } & 1 \\ \hline \text { HTML } & 1\end{array}\right]$

1. Ranking based on whether mean responses to questions are statistically different at the $5 \%$ level.

2. Items grouped with square brackets are not significantly different at the $5 \%$ level. 
Table 8 Significant differences between the views of group pairs and finance director subgroups

\begin{tabular}{|c|c|c|c|c|c|c|c|}
\hline Question (abbreviated) & EU-PS & EU-FD & PS-FD & EU-AP & PS-AP & FD-AP & $\mathrm{FD}_{\mathrm{L}}-\mathrm{FD}_{\mathrm{S}}$ \\
\hline \multicolumn{8}{|l|}{ Internet-based information } \\
\hline 1. Key information available & & $\mathrm{M}$ & $\mathrm{M}$ & $\mathrm{M}$ & $\mathrm{M}$ & & \\
\hline 2. Layer information & & $\mathrm{M}$ & $\mathrm{M}$ & & & & $\mathrm{M}$ \\
\hline 3. Provide templates & & $\mathrm{M}$ & $\mathrm{M}$ & $\mathrm{M}$ & $\mathrm{M}$ & & \\
\hline 4. Free search facility & & IA-M & $\mathrm{M}$ & & $\mathrm{M}$ & $\mathrm{L}$ & \\
\hline $\begin{array}{l}\text { 5(i). Place general meeting records on } \\
\text { web }\end{array}$ & & $\mathrm{M}$ & $\mathrm{M}$ & & & $\mathrm{L}$ & $\mathrm{M}$ \\
\hline $\begin{array}{l}\text { 5(ii). Place audio-visual record of } \\
\text { general meeting on web }\end{array}$ & & $\mathrm{M}$ & $\mathrm{M}$ & $\mathrm{M}$ & $\mathrm{M}$ & $\mathrm{L}$ & $\mathrm{M}$ \\
\hline $\begin{array}{l}\text { 5(iii). Broadcast/webcast general } \\
\text { meetings }\end{array}$ & & $\mathrm{M}$ & $\mathrm{M}$ & $\mathrm{M}$ & & & $\mathrm{M}$ \\
\hline 6. Place minutes of $1-1$ meetings on web & $\mathrm{L}$ & $\mathrm{M}$ & $\mathrm{M}$ & & $\mathrm{M}$ & $\mathrm{L}$ & \\
\hline 7. Webcast AGMs & & $\mathrm{M}$ & $\mathrm{M}$ & & & $\mathrm{L}$ & $\mathrm{M}$ \\
\hline $\begin{array}{l}\text { 8. Replace AGMs with online } \\
\text { questioning }\end{array}$ & $\mathrm{M}$ & & & & $\mathrm{L}$ & & \\
\hline \multicolumn{8}{|l|}{ 9. Periodic, not continuous updating } \\
\hline 10. Distinguish frequency of updating & & & $\mathrm{M}$ & & & $\mathrm{L}$ & \\
\hline \multicolumn{8}{|l|}{ Navigation and search aids } \\
\hline \multicolumn{8}{|l|}{ 1. Indexed on home page } \\
\hline \multicolumn{8}{|l|}{ 2. Hyperlinked table of contents } \\
\hline 3(i). Hyperlinks items/notes & & $\mathrm{M}$ & & & & & \\
\hline 3(ii). Hyperlinks items/OFR & & & & & & $\mathrm{L}$ & \\
\hline 3(iii). Hyperlinks items/time series & & & $\mathrm{M}$ & & $\mathrm{M}$ & & \\
\hline \multicolumn{8}{|l|}{ 4(i). Hyperlinks notes/OFR } \\
\hline 4(ii). Hyperlinks OFR/forward-looking & & & $\mathrm{M}$ & & & $\mathrm{L}$ & \\
\hline \multicolumn{8}{|l|}{ 4.(iii). Hyperlinks OFR/background } \\
\hline 5. Point and click time series graphs & & $\mathrm{M}$ & $\mathrm{M}$ & & $\mathrm{M}$ & & $\mathrm{M}$ \\
\hline \multicolumn{8}{|l|}{ 6. Next and previous buttons } \\
\hline \multicolumn{8}{|l|}{ 7. E-mail alerts } \\
\hline \multicolumn{8}{|l|}{ File formats/features } \\
\hline 1. HTML & $\mathrm{L}$ & & & & & & \\
\hline 2. PDF & $\mathrm{L}$ & & & & & & \\
\hline \multicolumn{8}{|l|}{ 3. Word-processed } \\
\hline 4. Spreadsheet & $\mathrm{M}$ & $\mathrm{M}$ & & $\mathrm{M}$ & & & \\
\hline 5. XBRL & $\mathrm{M}$ & & & & & & \\
\hline 6. Type tags & IA-M & IA-M & & & & & \\
\hline
\end{tabular}

Notes to table:

1. $\mathrm{EU}=$ expert users; $\mathrm{PS}=$ private shareholders; $\mathrm{FD}=$ finance directors; $\mathrm{AP}=$ audit partners; $\mathrm{IA}=$ investment analysts; $\mathrm{FM}=$ fund managers; $\mathrm{CL}=$ corporate lenders.

2. The letter ' $M$ ' indicates that the first group were more in agreement with the proposal or found the feature more useful than the second group, while the letter ' $\mathrm{L}$ ' indicates that the first group were less in agreement with the proposal or found the feature less useful than the second group.

3. Where there were significant differences between the three expert user groups, the specific expert user group giving rise to the difference is named.

4. $\mathrm{FD}_{\mathrm{L}}\left(\mathrm{FD}_{\mathrm{S}}\right)$ indicates finance directors of large (small) companies. 


\section{Appendix: Wording of questions as they appeared on the questionnaire}

\section{Internet-based information}

It is now clear that business reporting will increasingly occur via the Internet. This technology allows much larger information sets to be made available although, to avoid information overload, these will need to be structured to facilitate easy navigation and search. The questions in this section relate only to information provided using the Internet via company websites. They are based upon recent reports by accounting standard-setting bodies and professional bodies.

A3. How often do you use the Internet?
Never
Rarely
About once weekly
Almost daily

A4. To what extent do you agree or disagree that companies should be required to do the following?

- Make available key information that it uses to manage the company (subject to legitimate concerns re commercial confidentiality and risk of misinterpretation)

- Layer information to avoid information overload, while providing the detail desired by many (i.e. overview in top layer, becoming progressively more complex and detailed in lower layers)

- Provide a range of pre-packaged information, based on a standardised template for each group of users, specified by an external regulatory body. (The template gives a predefined structure and content to the information set that serves as a pattern for all companies. It would also include measures and discussion relevant to the specific perspective of the group.

- Maintain a facility on their website for free search (e.g. via provision of a search box), allowing users to retain control over the search and selection process (i.e. search software should support user-defined queries)

- To reduce unfair advantage, extend access to general company meetings with financial analysts/institutional shareholders by:

- placing records (i.e. presentation packs and slides) on website

- archiving an audio-visual record on website

- broadcasting live via satellite television channel or video webcast

- To reduce unfair advantage, extend access to one-to-one meetings by placing detailed minutes on website

- Teleconference (i.e. webcast) company AGMs to allow wider access

- Replace company AGMs by a facility for online questioning of management by users and conduct voting online

- Update business reporting information on websites periodically (e.g. quarterly or monthly), not continuously

- Distinguish clearly information that is continuously updated from more stable information that is updated only periodically

\section{Integration of information: navigation and search aids}

Companies can be expected increasingly to design their business reporting packages for the Internet medium, rather than simply placing an exact reproduction of the printed Annual Report and Accounts on their website. Listed here are features relating to the navigation and search aids that have been adopted by leading edge companies or demonstration sites.

A5. Please indicate how useful you think each of the following features would be in using an Internet-based business reporting package.

- Business reporting information is clearly indexed on the home page (e.g. titled Investor Relations) and not buried (e.g. under company history) 
- A hyperlinked site map or table of contents is available that shows all the major components in the business reporting package (hyperlinks allow the user to jump directly from one section to another, the link being activated by mouse-clicking on the source point)

- Hyperlinks exist between items in the financial statements and:

- the relevant note to the accounts

- the relevant section of the management discussion and analysis (known as the Operating and Financial Review (OFR) in the UK)

- the five-year summary

- Hyperlinks exist between the:

- individual notes to the accounts and the management discussion and analysis

- management discussion and analysis and relevant forward-looking information

- management discussion and analysis and relevant company background

- The facility to 'point and click' on financial items to get a time series graph of the item

- 'Next' and 'previous' buttons at the bottom of each page

- Users can sign up for e-mail alerts, to receive press releases and other updates via e-mail or notification that new information is posted on the web

\section{Portability of information - file formats}

A6. Please indicate how useful you think each of the following formats and features would be in using an Internet-based business reporting package.

- Information is presented as a combination of text and graphics in a format designed for the Internet (i.e. Hypertext Mark-up Language (HTML)); documents can be viewed directly in the web browser, but can only be re-entered into other programs by hand

- Information is presented as a Portable Document File (.pdf) that is produced by the Adobe Acrobat ${ }^{\mathrm{TM}}$ plug-in; data can only be transferred to other programs by cutting and pasting

- Text information is presented as word-processed files in proprietary format (e.g. Microsoft Word ${ }^{\mathrm{TM}}$ ) which can be down-loaded and used with these applications

- Financial statements are presented as spreadsheet files in proprietary format (e.g. Microsoft Excel ${ }^{\mathrm{TM}}$ ) which can be down-loaded and used with these applications

- Information is structured so that applications can exchange data easily by using Extensible Mark-up Language (XML) [Note: a financial reporting version (XFRML) is being developed by the US professional accountancy body]

- XFRML incorporates type tags that hook information together, allowing one company to be compared to others automatically

Note to appendix: On the actual research instrument, the questions spanned two-thirds of the width of the page, the response categories appearing on the final one-third. 